\title{
Bovine respiratory syncytial virus infection
}

\author{
Jean-Francois VALARCHER ${ }^{\mathrm{a}}$, Geraldine TAYLOR ${ }^{\mathrm{b} *}$ \\ a IVI-Animal Health, Lärkbacken, 74020 Vänge, Uppsala, Sweden \\ ${ }^{b}$ Institute for Animal Health, Compton, Newbury, Berkshire RG20 7NN, United Kingdom
}

(Received 6 April 2006; accepted 18 July 2006)

\begin{abstract}
Bovine respiratory syncytial virus (BRSV) belongs to the pneumovirus genus within the family Paramyxoviridae and is a major cause of respiratory disease in young calves. BRSV is enveloped and contains a negative sense, single-stranded RNA genome encoding 11 proteins. The virus replicates predominantly in ciliated respiratory epithelial cells but also in type II pneumocytes. It appears to cause little or no cytopathology in ciliated epithelial cell cultures in vitro, suggesting that much of the pathology is due to the host's response to virus infection. RSV infection induces an array of pro-inflammatory chemokines and cytokines that recruit neutrophils, macrophages and lymphocytes to the respiratory tract resulting in respiratory disease. Although the mechanisms responsible for induction of these chemokines and cytokines are unclear, studies on the closely related human $(\mathrm{H}) \mathrm{RSV}$ suggest that activation of NF- $\mathrm{KB}$ via TLR4 and TLR3 signalling pathways is involved. An understanding of the mechanisms by which BRSV is able to establish infection and induce an inflammatory response has been facilitated by advances in reverse genetics, which have enabled manipulation of the virus genome. These studies have demonstrated an important role for the non-structural proteins in anti-interferon activity, a role for a virokinin, released during proteolytic cleavage of the fusion protein, in the inflammatory response and a role for the SH and the secreted form of the G protein in establishing pulmonary infection. Knowledge gained from these studies has also provided the opportunity to develop safe, stable, live attenuated virus vaccine candidates.
\end{abstract}

BRSV / pathogenesis / respiratory disease / cattle / vaccines

\section{Table of contents}

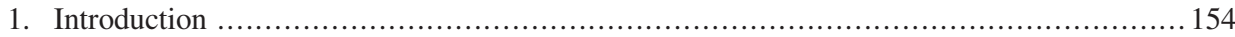

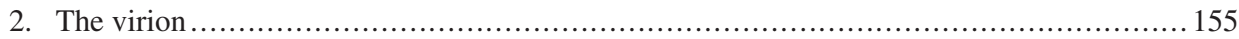

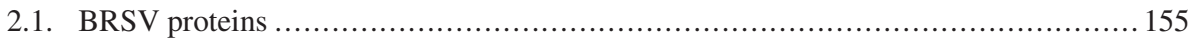

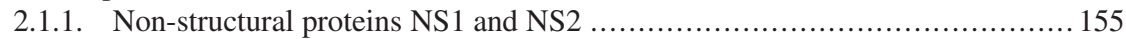

2.1.2. Small hydrophobic SH protein ........................................... 155

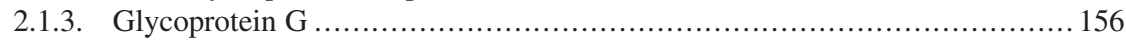

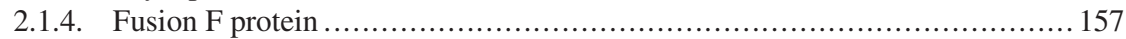

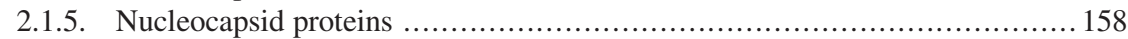

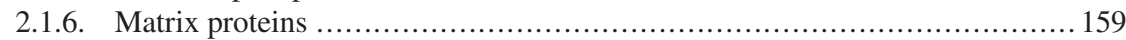

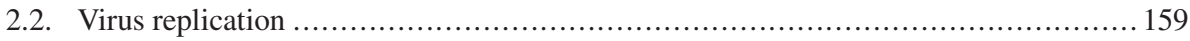

2.3. Antigenic and genetic subgroups of BRSV ............................................ 159

* Corresponding author: geraldine.taylor@bbsrc.ac.uk 
3. Epidemiology and clinical signs of disease ................................................... 160

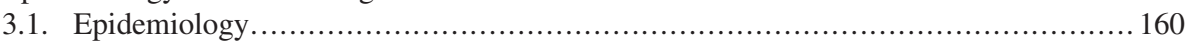

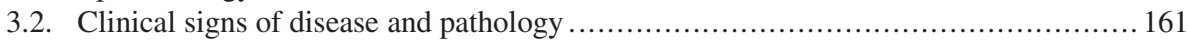

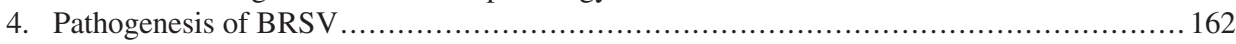

4.1. The role of the NS proteins in the pathogenesis of BRSV ............................. 163

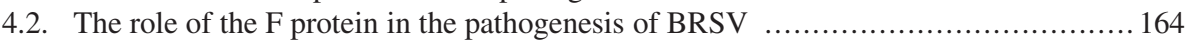

4.3. The role of the $\mathrm{G}$ protein in the pathogenesis of BRSV ................................ 165

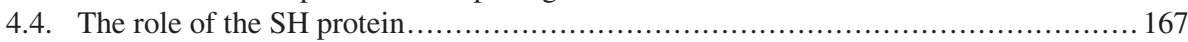

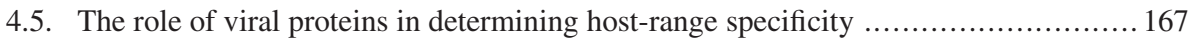

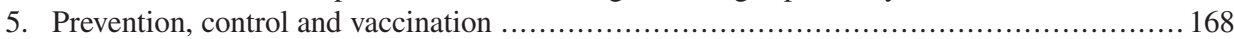

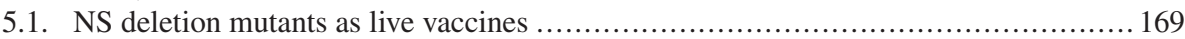

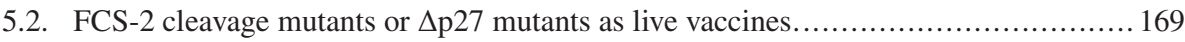

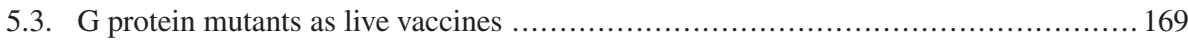

5.4. SH deletion mutants as live vaccines .................................................. 170

5.5. Other strategies for the development of live attenuated BRSV vaccine candidates ..... 170

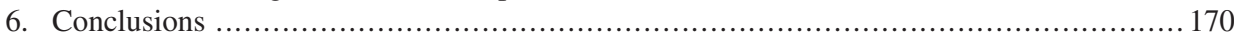

\section{INTRODUCTION}

Bovine respiratory syncytial virus (BRSV) is an enveloped, non-segmented, negative-stranded RNA virus and is a major cause of respiratory disease in young calves [128]. BRSV is closely related to human $(\mathrm{H}) \mathrm{RSV}$, which is a major cause of respiratory disease in young children, and the epidemiology and pathogenesis of infection with these viruses are similar [156]. These features make BRSV infection in calves a good model for the study of HRSV. In return, findings obtained by studying HRSV in vivo in humans, in small animal models or in vitro have allowed a better understanding of some virological and pathogenic characteristics of its counterpart in bovines. Although these viruses are very similar in many aspects, there are differences, such as their level of replication in vitro and in vivo in their respective hosts, differences in the peptide released as a result of cleavage at the two furin cleavage sites of the $\mathrm{F}$ protein and the relative functions of NS1 and NS2 in the inhibition of type I interferon induction.

HRSV and BRSV are members of the Pneumovirus genus within the subfamily Pneumovirinae, family Paramyxoviri- dae of the order Mononegavirales [26]. Other pneumoviruses include pneumonia virus of mice (PVM), ovine (O)RSV and caprine $(\mathrm{C}) \mathrm{RSV}$. Although the RS viruses are structurally and antigenically related, BRSV and CRSV are the most closely related [2, 82, 123, 147].

By electron microscopy, the morphology of the RSV virions appears to be either very pleomorphic, with a shape roughly rounded and a diameter between 150 and $35 \mathrm{~nm}$, or filamentous with a length that can reach $5 \mu \mathrm{m}$ and a diameter between 60 and $100 \mathrm{~nm}$ [147]. Regardless of the structure, each infectious particle contains a single functional copy of the genome. In contrast to HRSV, but similar to $80 \%$ of caprine virions, BRSV virions are organized in a network and viral particles are linked to each other by bridges of $12 \pm$ $3 \mathrm{~nm}$ [10]. The roles of these structures remain unexplained.

In contrast to HRSV, several vaccines against BRSV are available on the market. However, the development of a second generation of BRSV vaccines with greater efficacy in the presence of maternal antibodies and which induce more durable protection would be facilitated by a greater understanding of the pathogenesis of the 
virus. In this paper, after describing the characteristics of the virus and the disease induced by BRSV, we will review some recent findings on host-pathogen interactions that could provide a basis for the future development of safe, stable, live attenuated virus vaccines.

\section{THE VIRION}

The BRSV virion consists of a lipid envelope, derived from the host plasma membrane, containing three virally encoded transmembrane surface glycoproteins, which are organised separately into spikes on the surface of the virion (Fig. 1). These glycoproteins are the large glycoprotein $(\mathrm{G})$, the fusion protein $(\mathrm{F})$ and the small hydrophobic protein $(\mathrm{SH})$ [33]. The envelope encloses a helical nucleocapsid, which consists of the nucleoprotein $(\mathrm{N})$, phosphoprotein $(\mathrm{P})$, the viral RNA-dependent polymerase protein (L) and a genomic RNA of around 15000 nucleotides. In addition, there is a matrix $\mathrm{M}$ protein that is thought to form a layer on the inner face of the envelope and a transcriptional anti-termination factor M2-1. The genome also encodes an RNA regulatory protein $\mathrm{M} 2-2$ and two non-structural proteins, NS1 and NS2 [33] (Fig. 1). In addition, the viral particle contains cellular proteins, such as actin, which has been demonstrated on the surface of HRSV [148], caveolin-1 [18] and MHC class I molecules ${ }^{1}$. Thus, BRSV propagated in bovine cells can be neutralised by monoclonal antibodies specific for bovine MHC class I.

The genomic RNA is the template for replication and transcription. The genomic RNA, which is transcribed in a sequential fashion from the 3 ' end, encodes ten mRNA. There is a polar transcription gradient such that 3'-terminal genes are transcribed more frequently than those at the 5'

\footnotetext{
${ }^{1}$ Taylor G., unpublished observations.
}

end (Fig. 2). The 10 mRNA are then translated into 11 viral proteins. Some properties of the BRSV proteins and their amino acid (AA) identity with HRSV proteins are shown in Table I. The Pneumovirus genome is characterised by the existence of two non-structural proteins, NS1 and NS2, and a transcriptional overlap between M2 and L that lead to the synthesis of M2-1 and M2-2 proteins.

\subsection{BRSV proteins}

\subsubsection{Non-structural proteins NS1 and NS2}

One of the major differences between the pneumoviruses and the other Paramyxoviridae is the presence of two nonstructural (NS) proteins, NS1 and NS2, which have 136 AA and 124 AA, respectively [102]. The genes encoding these two proteins are abundantly transcribed in virus-infected cells, however, the proteins are detected only in trace amounts in purified virions. There is evidence that the HRSV NS1 protein coprecipitates with the $M$ protein [42], and is a strong inhibitor of viral RNA transcription and replication [7]. The NS2 protein also appears to be a transcriptional inhibitor but at a lower level than the NS1 protein [7]. The NS2 protein colocalizes with the $\mathrm{P}$ and $\mathrm{N}$ proteins in infected cells [164] but does not coprecipitate with any viral protein [42]. These proteins are not essential for virus replication in vitro, although the growth of recombinant HRSV and BRSV lacking one or other of these proteins is attenuated in cell culture $[20,115,137]$. The NS1 and NS2 proteins play an important role in regulating IFN $\alpha / \beta$ and their role in the pathogenesis and host-range restriction of BRSV is discussed below.

\subsubsection{Small hydrophobic $\mathrm{SH}$ protein}

The SH protein is a short integral membrane protein and is not essential for virus 


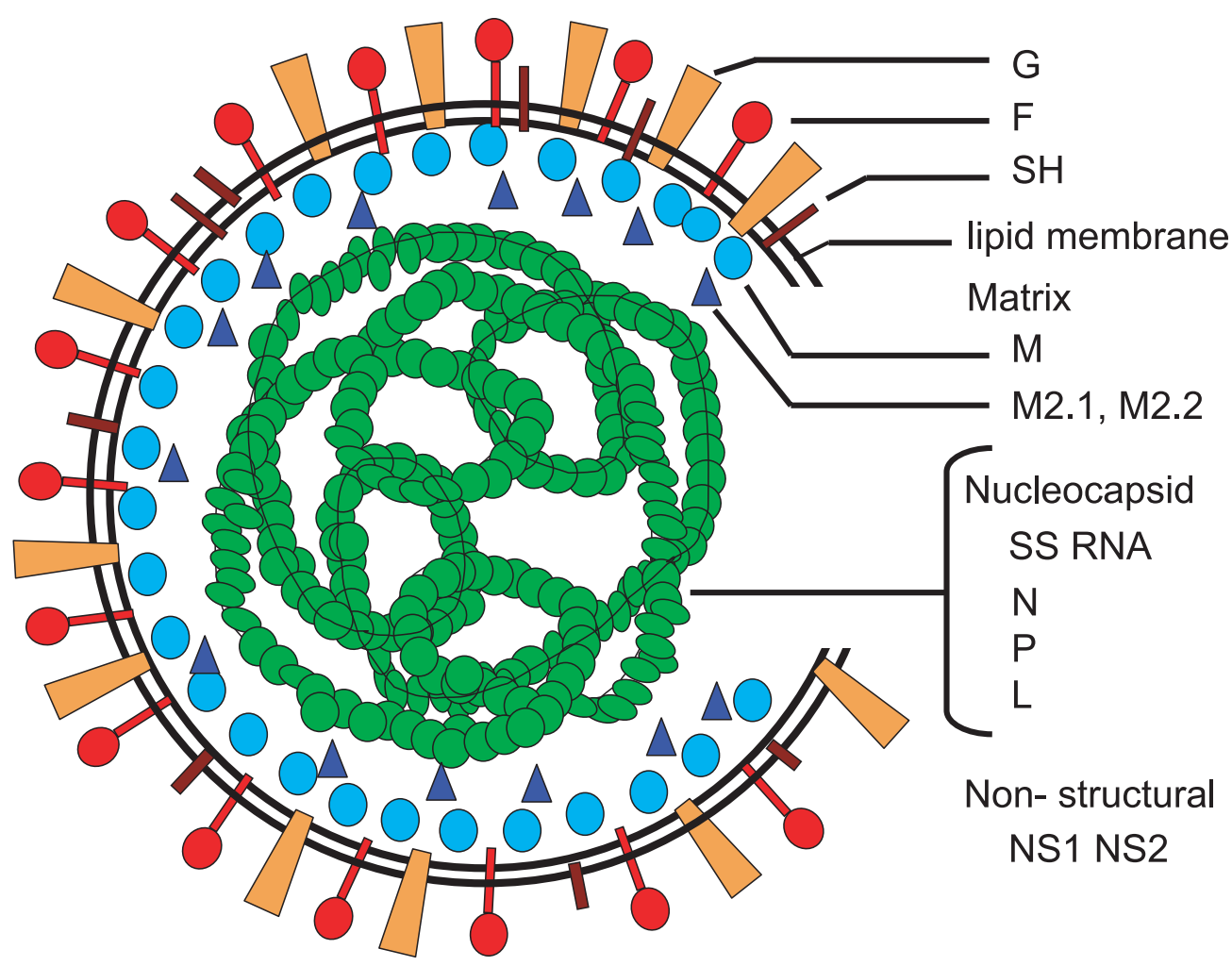

Figure 1. Diagram of bovine respiratory syncytial virus.

replication in vitro or in vivo and its function is not well defined [65]. This protein is $81 \mathrm{AA}$ [111] and varies by up to $13 \%$ between different BRSV isolates [109]. The SH protein of HRSV exists as different forms, SHg (13-15 kDa), SHp (21$30 \mathrm{kDa})$, non-glycosylated SH0 (7.5 kDa) and a nonglycosylated form SHt (4.8 kDa) which is derived from initiation at a second methionine in the open reading frame (ORF) [4, 111]. There is evidence that the SH protein may play a role in virusmediated cell fusion by interacting with the F protein $[43,59]$.

\subsubsection{Glycoprotein G}

The G glycoprotein is 257AA or 263AA depending upon the BRSV isolate [92] and it is a type II glycoprotein with a signal/anchor domain between AA residues 38 and 66. The $\mathrm{G}$ protein was identified as the major attachment protein because antibodies specific to the $G$ protein blocked the binding of virus to cells [86] and it is a major protective antigen of BRSV [132, 133]. However, the G protein is structurally different from its counterparts in other paramyxoviruses (HN and $\mathrm{H}$ proteins) $[78,79,165]$ and is a heavily glycosylated nonglobular protein similar to cellular mucins. The $\mathrm{G}$ protein is synthesised as two forms, a membrane-anchored form and a secreted form [60,61], which arises from translational initiation at a second AUG in the ORF [108]. Around 80\% of the $\mathrm{G}$ protein is produced as the secreted form $24 \mathrm{~h}$ after infection [61]. 
Table I. BRSV proteins.

\begin{tabular}{|c|c|c|c|c|c|}
\hline$\overline{\text { Proteir }}$ & Protein name & $\begin{array}{l}\text { Size } \\
\text { (AA) }\end{array}$ & $\begin{array}{l}\% \text { AA } \\
\text { identity } \\
\text { with } \\
\text { HRSV }\end{array}$ & $\mathrm{M}_{\mathrm{r}}(\mathrm{kd})$ & Functions \\
\hline$\overline{\mathrm{NS} 1}$ & Non-structural protein 1 & 136 & $69[102]$ & 13.8 & Inhibition of and resistance to IFN $\alpha / \beta$ \\
\hline NS2 & Non- structural protein 2 & 124 & $84[102]$ & 14.5 & Inhibition of and resistance to IFN $\alpha / \beta$ \\
\hline $\mathrm{F}$ & Fusion protein & 574 & $81[84]$ & 70 & Membrane fusion \\
\hline G & Glycoprotein & 257 & $30[83]$ & 90 & Attachment \\
\hline SH & $\begin{array}{l}\text { Small } \\
\text { hydrophobic protein }\end{array}$ & 73 & $\begin{array}{l}38-44 \\
{[4]}\end{array}$ & $7.5-60$ & Unknown function \\
\hline M & Matrix protein & 256 & 89 [111] & 25 & Virion assembly \\
\hline M2-1 & Matrix protein 2-1 & 186 & 80 [172] & 22 & Trancription anti-termination factor \\
\hline M2-2 & Matrix protein 2-2 & 95 & $43[172]$ & 11 & RNA regulatory protein \\
\hline $\mathrm{N}$ & Nucleoprotein & 391 & 93 [112] & 45 & $\begin{array}{l}\text { Binds to genomic and anti-genomic RNA } \\
\text { to form RNAse-resistant nucleocapsid }\end{array}$ \\
\hline $\mathrm{P}$ & Phosphoprotein & 241 & $81[91]$ & 33 & Chaperonin and polymerase co-factor \\
\hline $\mathrm{L}$ & Polymerase protein & 2161 & $84[171]$ & 250 & RNA dependent RNA polymerase \\
\hline
\end{tabular}

The BRSV $G$ protein appears as a trimer at the surface of the virion and contains several independently folded regions, in which the ectodomain consists of a conserved central hydrophobic region located between two polymeric mucin-like regions [31,77-80, 166]. This conserved central hydrophobic region contains four conserved cysteine residues, which form two disulphide bridges. However, in some field isolates of BRSV, one or several of the cysteines is mutated to either an alanine or an asparagine $[126,150]$. The major epitope of this region is located at the tip of a loop, overlapping a relatively flat surface formed by the double disulphidebonded cysteine noose and lined by highly conserved residues $[78,79]$. This epitope appears to be immunodominant [79] and the effect of the loss of one or more cysteines on antibody recognition has not been determined.

The G protein of HRSV and BRSV probably favours the attachment of the virion at the cell surface by the in- teraction of its heparin-binding domains with glycosaminoglycans on cell membranes [138]. In addition, the $G$ is suspected to have other roles by interacting with the immune system. It has been proposed that the secreted form might act as a decoy by binding to neutralising antibodies. Furthermore, the conserved cysteine rich region has homology with the CX3C chemokine motif, which may facilitate infection by interacting with the CX3C chemokine receptor, CX3CR1 [146]. The $\mathrm{G}$ protein may also interact with L-selectin (CD62L), annexin II [90], and surfactant proteins $[48,62]$. The role of the $\mathrm{G}$ protein in the pathogenesis of BRSV infection will be discussed below.

\subsubsection{Fusion F protein}

The $\mathrm{F}$ protein mediates binding of virus to cells and is responsible for virus penetration by fusion between the viral and host cell membranes, delivering the nucleocapsid to the cytoplasm. It is also 


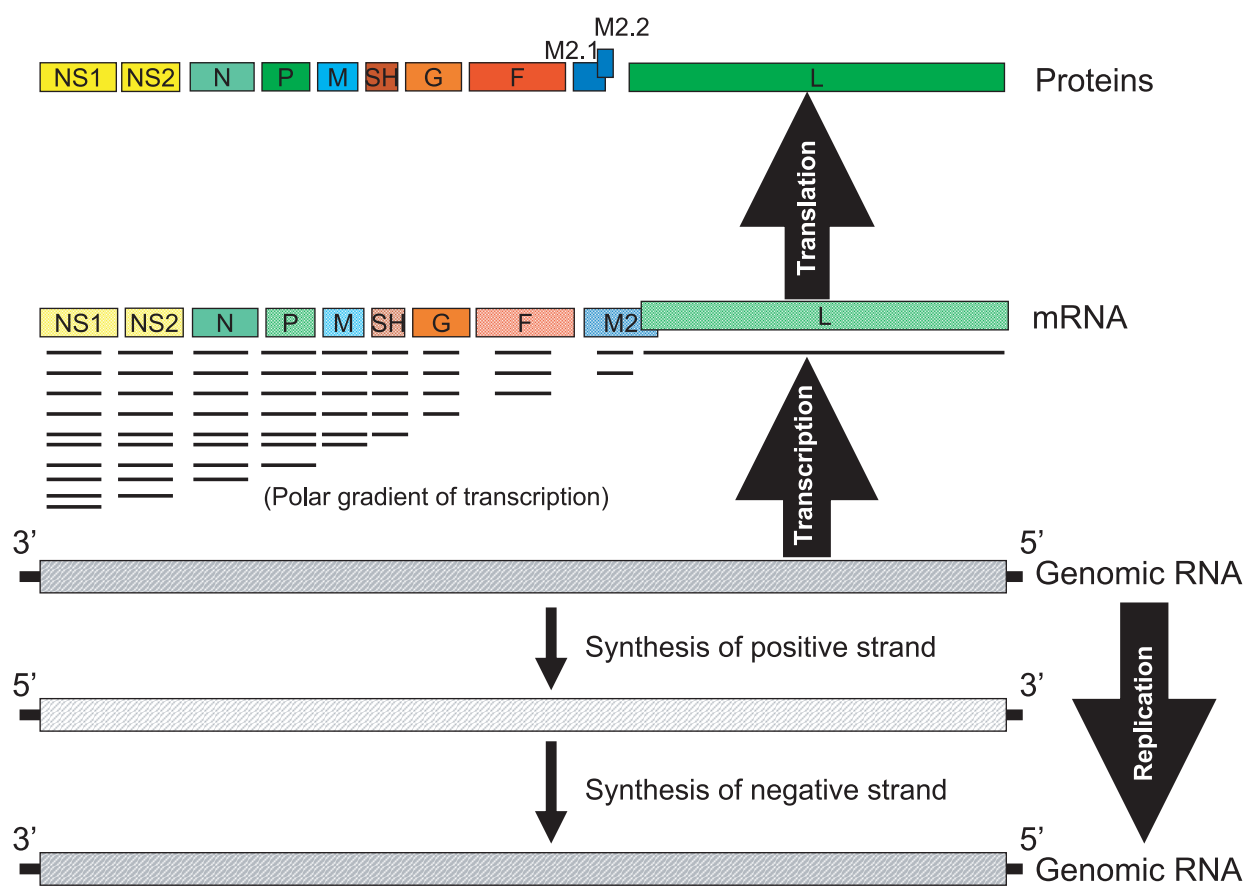

Figure 2. Transcription, translation and replication of bovine respiratory syncytial virus RNA. (A color version of this figure is available at www.edpsciences.org/vetres.)

responsible for the fusion of the cellular membranes between infected and noninfected cells that give rise to syncytia or multinucleated giant cells. The $\mathrm{F}$ protein induces neutralising antibodies and confers resistance to BRSV infection [130, $132,134,144]$. The protein $\mathrm{F}$ of BRSV is 574 AA $[84,101]$ and is highly conserved between different BRSV isolates. Partial sequence analysis of a number of different isolates has demonstrated amino acid and nucleotide variation of $1.8 \%$ and $0.8 \%$ respectively [150]. The $\mathrm{F}$ protein, which is indispensable to virus replication, is synthesised as an inactive precursor, F0, which has to be proteolytically cleaved at two furin consensus sequences to yield a fusion-active, disulphide-linked heterodimer composed of the F2 and F1 subunits $[49,174]$. Cleavage is accompanied by the release of a small peptide composed of 27 amino acids (pep27) originally located between the two cleavage sites $[175,176]$, which has homology with tachykinins, a family of bioactive peptides. The role of the $\mathrm{F}$ protein cleavage sites and of pep27 in the pathogenesis of BRSV will be discussed below.

\subsubsection{Nucleocapsid proteins}

The nucleocapsid is constituted by the nucleoprotein $(\mathrm{N})$, the phosphoprotein $(\mathrm{P})$ and the polymerase (L). The nucleoprotein has a length of 391 AA [112] and variation between different BRSV isolates is $1.5 \%$ and $0.7 \%$ at the nucleotide and AA levels respectively. Vaccination with recombinant vaccinia virus expressing the $\mathrm{N}$ protein can induce some protective immunity against BRSV [132]. Since this protein is recognised by BRSV-specific 
bovine $\mathrm{CD}^{+} \mathrm{T}$ cells [46], protection induced by this proteins may be mediated by cytotoxic $\mathrm{T}$ cells. The $\mathrm{N}$ protein is present in large amounts in the virion and in infected cells and has several functions. In combination with $\mathrm{P}, \mathrm{L}$ and possibly M2-2, the $\mathrm{N}$ protein is a major element of the nucleocapsid and protects the viral genome RNA from RNAse $[93,112]$. The $\mathrm{N}$ protein seems to play a role in the transition between the transcription and the replication phases of the viral RNA [93]. The P protein has 241 AA [2] and appears to act as a chaperone for soluble $\mathrm{N}$ and is implicated as a regulation factor for viral transcription and replication. The polymerase $\mathrm{L}$ of BRSV has a size of 2162 AA [171] and is an RNA-dependant RNA polymerase. This protein is responsible for the viral transcription and replication [171].

\subsubsection{Matrix proteins}

In contrast to the Paramyxoviridae, RSV has 3 matrix proteins. The M protein is $256 \mathrm{AA}$ in length and has little sequence relatedness with other paramyxovirus M proteins. This protein is located on the inner surface of the viral envelope and plays an important role in the formation of virus-like particles [136]. The M2-1 and M2-2 proteins are both encoded by the M2 mRNA, which contains two overlapping translational ORF [30]. The upstream ORF1 encodes the M2-1 protein (194 AA) and the downstream ORF2 encodes the M2-2 protein (83-90 AA) [1,14]. The M2-1 protein is an anti-termination factor that promotes transcriptional chain elongation and increases the frequency of readthrough at gene junctions [57]. The M2-2 protein mediates a regulatory switch from transcription to RNA replication [14].

\subsection{Virus replication}

Following fusion of the viral envelope and the cell membrane, the ribonucleopro- tein (RNP) complex is released into the cytoplasm and transcription of the viral RNA by the polymerase begins. Transcription involves a sequential start-stop mechanism that produces subgenomic RNA. It is guided by short conserved signals that flank each mRNA coding unit, namely a transcription gene start (GS) signal and a termination/polyadenylation gene end (GE) signal $[73,74]$. There is a polar transcription gradient with promoter-proximal genes being transcribed more frequently than downstream genes. RNA replication occurs when the polymerase switches to a readthrough mode resulting in the synthesis of a positive-sense replicative intermediate which acts as a template for replicating the negative strand genomic RNA (Fig. 2). Both genomic and antigenomic RNA are packaged. The nucleocapsids are assembled in the cytoplasm and then migrate with the $\mathrm{M}$ protein toward the cellular membrane in which viral glycoproteins are present. The viral budding might occur directly at the surface of the cellular membrane or into cytoplasmic vesicles [6]. In polarised airway epithelial cells, budding of HRSV occurs at the apical surface [173] and this is also true for BRSV infection of polarised bovine airway epithelial cells, in vitro ${ }^{2}$.

\subsection{Antigenic and genetic subgroups of BRSV}

Antigenic and genetic subtypes have been defined for BRSV through several studies [44, 81, 98, 120, 150]. Using monoclonal antibodies $(\mathrm{mAb})$ directed against the $G$ protein, a classification into four antigenic subgroups, $\mathrm{A}, \mathrm{B}, \mathrm{AB}$ and untyped, has been established for BRSV [44, 120]. Until recently, isolates of subgroup B BRSV had not been detected since 1976 [126]. The existence of six genetic

\footnotetext{
${ }^{2}$ Valarcher J.F., Sadler R., Taylor G., unpublished observations.
} 
subgroups based on $\mathrm{G}$ and of five based on $\mathrm{F}$ or $\mathrm{N}$ has also been established [150]. This classification showed a spatial clustering of BRSV isolates that has been confirmed by studies including isolates collected in many countries $[126,154,170]$. The degree of genetic variability of BRSV is limited being less than $15 \%$, which is less than that observed within one subgroup of HRSV [105]. The evolution of BRSV appears to be continuous and it has been proposed that evolution may be driven by selective pressure as a result of the immune response induced by vaccination [150].

The biological significance of these subgroups is not known. However, polyclonal sera obtained from calves vaccinated with the BRSV $G$ protein from subgroup A virus recognised a different subgroup $\mathrm{A}$ BRSV but not a subgroup B or an untyped isolate [45]. Furthermore, recognition of a subgroup $A B$ virus was less than that of the subgroup A isolate. Thus, mutations in the immunodominant region (AA 174-188) of the $\mathrm{G}$ protein may contribute to the lack of cross-protection between vaccine and field isolates. This might be relevant for the development of subunit vaccines.

\section{EPIDEMIOLOGY AND CLINICAL SIGNS OF DISEASE}

\subsection{Epidemiology}

Although cattle are the natural host of BRSV, it is possible that other species such as ovine, caprine, bison, chamoix or camelids may play an epidemiological role in certain circumstances [29, 40, 107, 113, 157]. The distribution of BRSV is worldwide and the virus has been isolated from cattle in Europe, America and Asia $[63,100,122]$. The virus causes regular winter outbreaks of respiratory disease in cattle [127]. A seroprevalence of 30 $70 \%$ have been detected in cattle $[3,41,54]$. The frequency of BRSV infections is very high and the virus might be responsible for more than $60 \%$ of the epizootic respiratory diseases observed in dairy herds $[9,41,149]$ and up to $70 \%$ in beef herds $[27,114$, 127]. The frequency of BRSV infections is correlated to the density of the cattle population in an area [41] and the age of the animal. Indeed more than $70 \%$ of beef calves were infected with BRSV by the age of nine months in England [127] and in cattle less than one year old in The Netherlands [70]. BRSV antibodies in calves between 5 and 11 months of age were detected in $35 \%$ of dairy herds $(n=$ 118) in a Swedish study [54]. The frequency of infection in adults is difficult to assess because of the high BRSV seroprevalence in this category of animals.

Severe clinical signs are mainly observed in calves [70,127, 160], but might also be observed in adult cattle [41]. The higher frequency of clinical signs induced by BRSV in young calves compared with adults can be explained by the level of specific immunity following frequent exposure to the virus. Indeed clinical signs are usually observed in cattle of all ages when BRSV is introduced in herds where most of the animals are naïve to the virus and are observed only in calves when the virus circulates regularly in the herd [156]. Maternally derived antibodies provide at least partial protection against clinical signs after natural and experimental BRSV infection [11,68-70]. Although virus shedding has occasionally been detected upon experimental BRSV re-infection, little or no clinical disease is observed in reinfected animals [69, 109, 134, 145]. Similar to observations made for HRSV [67], exacerbated clinical signs have been observed following a natural BRSV infection in animals immunised with inactivated vaccines $[5,47,119]$.

BRSV infection is associated with a high morbidity (60 to $80 \%$ ) and mortality can reach up to $20 \%$ in some outbreaks. Clinical disease caused by BRSV is mainly 
diagnosed in the autumn and winter in temperate climate zones [127]. Although BRSV infection occurs mainly in these seasons [155], it might also occur in the summer [41]. BRSV is mainly transmitted by direct contact between infected animals or by aerosol [94] but it cannot be excluded that it might also be spread by humans acting as a passive vector as observed for HRSV [55]. Some data indicate that BRSV may persist in infected animals [39, 140, 151]. However attempts to demonstrate re-excretion of BRSV from previously infected animals by treatment with 3-methyl indol, BVDV, BHV1 or dexamethasone have failed [158] and transmission of virus from carriers to susceptible animals has not been proven.

\subsection{Clinical signs of disease and pathology}

The incubation period for BRSV is estimated to be between 2 and 5 days. BRSVinfection may either be asymptomatic, limited to the upper airways or involve both the upper (URT) and lower respiratory tracts (LRT). URT disease is characterised by a cough with a seromucoid nasal and ocular discharge. In more severe infections, there is slight depression and anorexia, a decrease in milk yield in lactating cows, hyperthermia, polypnea (respiratory rate $\geq 60$ movements per min) and an abdominal dyspnea. On auscultation of the lung abnormal breathing sounds caused by bronchopneumonia or bonchiolitis might be detected [159]. Animals may develop severe respiratory distress with a grunting expiration and breathing through an open mouth with the neck stretched and the head down, with saliva poring on the floor and with the tongue out. In these animals, pulmonary emphysema and oedema with some crackles and wheezes may be detected [12] and in some cases subcutaneous emphysema might occur $[12,19]$.
At necropsy, a broncho-interstitial pneumonia may be observed $[19,161]$. Areas of the cranio-ventral parts of the lung are consolidated and a mucopurulent discharge may be seen from the bronchus and small bronchi. The caudo-dorsal parts of the lungs are often distended because of interlobular, lobular and sub-pleural emphysematic lesions [19]. Tracheobronchial and mediastinal lymph nodes may be enlarged, oedematous and sometimes haemorrhagic. If bacterial super-infections occur, the lung parenchyma is more swollen and consolidated and fibrin or suppurative bronchopneumonia may be observed.

Microscopic lesions are characterised by a proliferative and exudative bronchiolitis with accompanying alveolar collapse and a peribronchiolar infiltration by mononuclear cells [141]. Necrosis of the epithelium and apoptotic epithelial cells, which may be phagocytosed by neighbouring cells, can be seen [162]. Giant cells or syncytia may be present, either free in the bronchi lumen, in the bronchiolar epithelium or in the alveolar walls and lumina [162]. The lumen of bronchi, bronchioles and the alveoli are often obstructed by cellular debris consisting mostly of neutrophils, desquamated epithelial cells, macrophages and sometimes eosinophils [162] and may be aggravated by bronchiolar repair and reorganisation [71]. Eosinophils and lymphocytes $\left(\mathrm{CD}^{+}, \mathrm{CD}^{+}\right.$and $\mathrm{WC}^{+} \gamma / \delta \mathrm{T}$ cells) are also observed in the lamina propria [141, 143, 162]. Alveolar changes are marked by an interstitial pneumonia and atelectasis in the consolidated areas and there may be severe emphysema and oedema with a rupture of alveolar walls in the caudo-dorsal area of the lung. The presence of microscopic changes in the caudo-dorsal area are rarely associated with the presence of BRSV antigen, syncytia or bronchiolitis [71]. An alveolar epithelisation with a pneumocyte hyperplasia 
contributes to the enlargement of the alveolar septa with the cell infiltration. Hyaline membranes may be present in the alveoli following inflammation and pneumocyte necrosis [19].

\section{PATHOGENESIS OF BRSV}

BRSV replicates primarily in the superficial layer of the respiratory ciliated epithelium and replication can also be detected in type II pneumocytes [161, 162]. Although BRSV is cytopathic in tissue culture, little or no cytopathic effects are seen following infection of differentiated bovine airway epithelial cell cultures, in vitro ${ }^{3}$. A similar lack of obvious cytopathology has been observed in human airway epithelial cell cultures infected with HRSV [173], suggesting that the host response to virus infection plays a major role in RSV pathogenesis.

HRSV infection of human airway epithelial cells and alveolar macrophages results in activation of NF- $\mathrm{KB}$ which leads to the induction of inflammatory chemokines and cytokines, such as RANTES (CCL5), MIP-1 $\alpha$ (CCL3), MCP-1 (CCL2), eotaxin (CCL11), IL-8 (CXCL8), TNF- $\alpha$, interleukin (IL)-6, IL-1 etc. $[15,52,53,58,95$, 99], which contribute to inflammation by recruiting neutrophils, macrophages and lymphocytes to the airways. Although less well studied, BRSV infection induces a similar up-regulation of pro-inflammatory chemokines and cytokines in the bovine lung. Thus, increased levels of mRNA for IL-12, IFN $\gamma$, TNF $\alpha$, IL-6, IL-18, IL-8, RANTES, MCP-1, MIP-1 $\alpha$, IFN $\alpha$ and IFN $\beta$ have been detected in pneumonic lesions from BRSV-infected gnotobiotic calves ${ }^{4}$. The molecular mecha-

\footnotetext{
${ }^{3}$ Sadler R., Valarcher J.-F., Hibbert L., Taylor G., unpublished observations.

${ }^{4}$ Hibbert L., Valarcher J.-F., Taylor G., unpublished observations.
}

nisms involved in RSV-induced activation of NF- $\mathrm{KB}$ and initiation of the innate response are complex and appear to be mediated, at least in part by the interaction of the $\mathrm{F}$ protein with Toll-like receptor 4 (TLR4) [75] and by the interaction of dsRNA with TLR3 [110] (Fig. 3). Although TLR4 is expressed at high levels by macrophages and dendritic cells (DC) it is expressed only at very low levels on airway epithelial cells. However, HRSV infection increases TLR4 expression on human airway epithelial cells and increases their responsiveness to LPS [96]. Studies in BALB/c mice infected with HRSV demonstrated two peaks of NF- $\kappa \mathrm{B}$ activation. The immediate response following RSV inoculation was TLR4-dependent [52] and the second peak, which required RSV replication was mediated via TLR3 signalling pathways [110]. It is likely, but has not been formally demonstrated, that BRSV infection induces activation of $N F-\kappa B$ and induction of pro-inflammatory cytokines by pathways similar to those demonstrated for HRSV.

An understanding of the mechanisms by which BRSV is able to establish infection in the bovine respiratory infection, induce an inflammatory response and respiratory disease has been greatly facilitated by advances in reverse genetics. This involves the production of infectious virus from cloned cDNA $[32,37]$. The recovery of $\mathrm{RSV}$ from cDNA requires co-expression in cell culture of a complete copy of the viral RNA genome and the N, P, M2-1 and $\mathrm{L}$ proteins engineered to be expressed by bacteriophage T7 RNA polymerase. As described above, these are the constituents of the nucleocapsid and polymerase complex, which is the minimum unit of infectivity for mononegaviruses. The expressed viral components assemble and result in a productive infection. The recombinant virus produced in this way is identical to the biologically-derived virus except for whatever mutations have been introduced into 


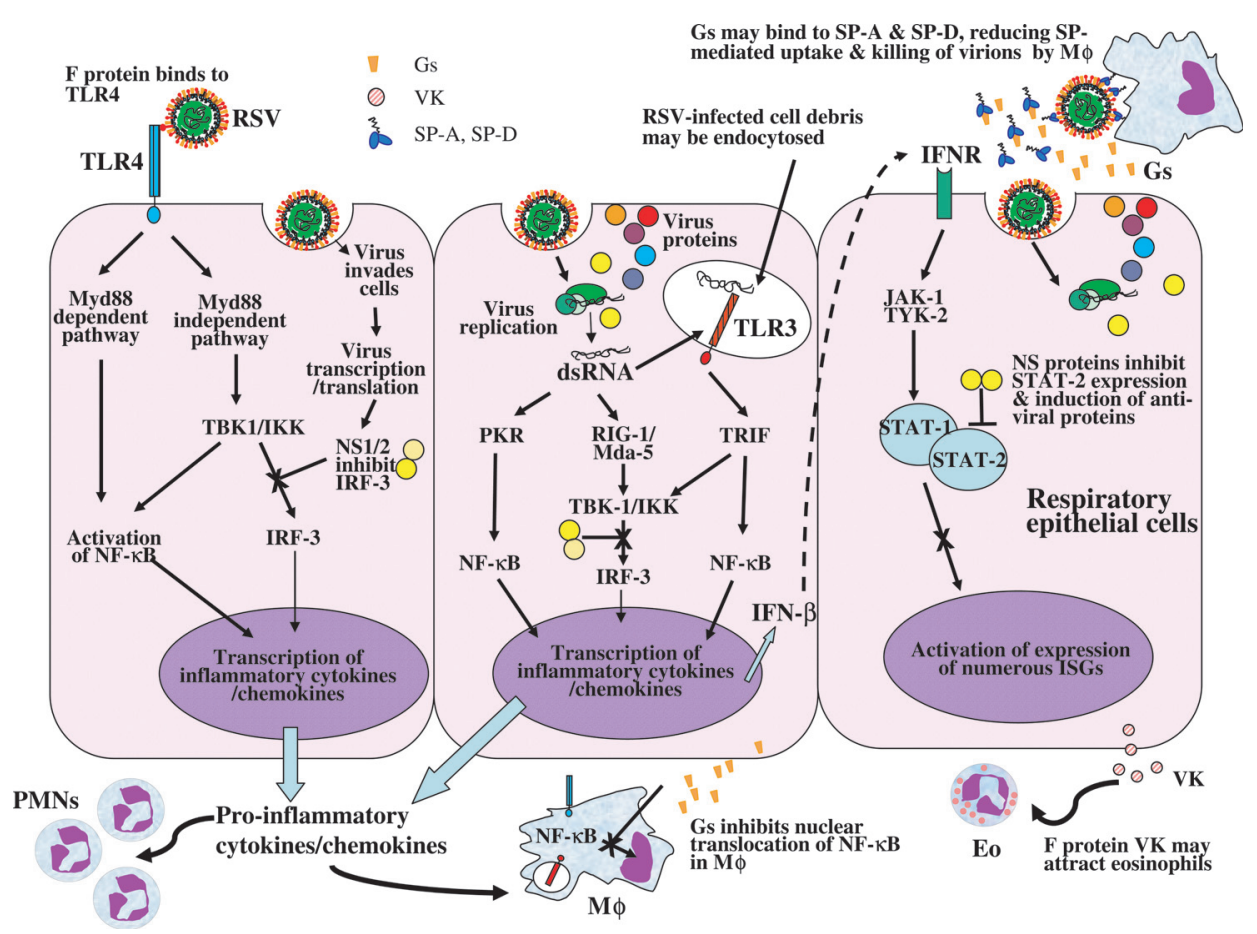

Figure 3. Molecular mechanisms involved in the initiation of the innate response to RSV. BRSV attaches to respiratory epithelial cells via glycosaminoglycans and possibly other receptors. The interaction of the F protein with TLR4 leads to activation of NF- $\mathrm{KB}$ via the Myd88-dependent pathway. Double-stranded (ds)RNA, a by-product of virus replication, leads to activation of the transcription factors NF- $\mathrm{KB}$, IRF-3 and AP-1 (not shown), which act cooperatively to fully activate the IFN $\beta$ promoter. The BRSV NS proteins block activation of IRF-3, inhibiting the induction of IFN $\beta$. Any IFN produced as a result of BRSV infection binds to the type I interferon receptor (IFNR) and activates the expression of numerous interferon stimulated genes (ISG) via the JAK/STAT pathway, which establishes an antiviral state and the activation of IRF-7 which amplifies the IFN response. The NS proteins decrease STAT2 expression and inhibit IFN signalling. Activation of NF- $\mathrm{kB}$ via TLR4 and TLR3 leads to the induction of pro-inflammatory cytokines and chemokines and recruitment of polymorphonuclear neutrophils (PMN), macrophages $(\mathrm{M} \phi)$ and NK cells to the sites of infection. The soluble form of the G protein (Gs) may compete with the virus for binding to surfactant proteins (SP-A and SP-D) and may act to inhibit the early innate response by suppressing the activation of NF- $\mathrm{kB}$. The virokinin (VK) released following cleavage of the BRSV F protein may contribute to eosinophil (Eo) recruitment or to bronchoconstriction.

the cDNA. The role of different proteins in the pathogenesis of BRSV has been investigated by analysing the effects of deleting genes or introducing mutations in the cDNA copy of the virus genome. Some of these studies are described below.

\subsection{The role of the NS proteins in the pathogenesis of BRSV}

Interferon (IFN) $\alpha / \beta$ are produced by most eukaryotic cells in response to virus infection and establish a first line of 
defence. Transcription of IFN $\alpha / \beta$ is mediated by the transcription factors IRF-3, $\mathrm{NF}-\kappa \mathrm{B}$ and AP-1. Once secreted, IFN $\alpha / \beta$ bind to cell surface receptors and activate the JAK/STAT signalling pathway which induces further production of IFN and an array of IFN-stimulated genes, including ones that establish an antiviral state [50] (Fig. 3). In order to establish infection, viruses have evolved a variety of mechanisms to counteract the IFN $\alpha / \beta$ response. BRSV and HRSV are poor inducers of IFN $\alpha / \beta$ and are resistant to the antiviral effects of IFN $\alpha / \beta[8,115]$. The ability to regulate the IFN $\alpha / \beta$ response is mediated by the NS proteins of BRSV and HRSV [16, 17, 115, 124, 152]. The BRSV NS2 protein appears to have a greater inhibitory effect on IFN $\alpha / \beta$ than the NS1 protein, which is the converse of that described for HRSV [124, 152]. The BRSV and HRSV NS proteins prevent induction of IFN $\alpha / \beta$ and the establishment of an antiviral state by interfering with the activation of IRF-3 [17, 125] (Fig. 3). In addition, the HRSV NS proteins inhibit IFN $\alpha / \beta$ signalling by inducing a decrease in Stat2 expression [87, 106] (Fig. 3). Further studies have demonstrated that the NS genes may also play a role in activation of $\mathrm{NF}-\kappa \mathrm{B}$. Thus, activation of NF- $\kappa \mathrm{B}$ in Vero cells, which lack IFN $\alpha / \beta$ structural genes, infected with rHRSV lacking NS2 ( $\triangle \mathrm{NS} 2)$ or lacking both NS1 and NS2 ( $\triangle \mathrm{NS} 1 / 2)$ was significantly lower than that in cells infected with wild-type HRSV [125]. The role of the BRSV NS proteins in NF- $\mathrm{KB}$ activation is not known.

Although the NS proteins are not essential for virus replication in vitro, growth of recombinant BRSV lacking one or the other of these proteins is attenuated in cell culture $[20,115,152]$. Furthermore, replication of NS deletion mutants of BRSV in young calves is highly attenuated [152]. Thus, following intranasal (i.n.) and intratracheal (i.t.) inoculation of 2 week-old, gnotobiotic calves with rBRSV $\triangle \mathrm{NS} 1$ or
rBRSV $\triangle \mathrm{NS} 2$, only low titres of virus could be isolated from the nasopharynx for only 1 to 2 days and virus could not be detected in the lungs at post-mortem, 6 to 7 days after infection. BRSV lacking both NS1 and NS2 was even more attenuated and virus could not be recovered from calves at any time post-infection. In contrast to calves infected with wild-type rBRSV, neither macroscopic nor microscopic lung lesions could be detected in any of the calves inoculated with any of the NS deletion mutants. These observations highlight the critical role of IFN $\alpha / \beta$ in the innate response of the bovine respiratory tract against BRSV infection.

\subsection{The role of the $F$ protein in the pathogenesis of BRSV}

Cleavage of the BRSV F0 protein by a furin endoprotease occurs at two sites, FCS-1 (RKRR $\left.{ }^{136}\right)$ and FCS-2 $\left(\mathrm{RAR} / \mathrm{KR}^{109}\right)$, and results in the formation of F1 and F2 subunits linked by a disulphide bridge and in the release of an $\mathrm{N}$-glycosylated peptide of 27 amino-acids (pep27) [49, 174]. Cleavage at both sites is required for efficient syncytium formation. In BRSV-infected cells, pep27 is further subjected to post-translational modifications and is converted into virokinin, a member of the tachykinin family, which includes substance $\mathrm{P}$, neurokinins $\mathrm{A}$ and $\mathrm{B}$, hemokinin and endokinin A and B [176]. Virokinin induces smooth muscle contraction, in vitro, and may therefore contribute to bronchoconstriction in vivo. Using recombinant (r)BRSV with mutations in FCS-2 (K108N/K109/N) that abolished cleavage at this site or in which pep27 was deleted $(\Delta \mathrm{p} 27)$, neither FCS-2 nor pep27 was found to be essential for virus replication in vitro $[72,176]$. However, mutant BRSV in which cleavage was abolished at FCS-2 did not grow as efficiently as the parental wild-type virus during early replication cycles. Furthermore, 
both rBRSV (108/109) and $\Delta$ p27 showed reduced syncytium formation in cell culture [176].

Despite the differences seen in vitro with these viruses, they replicated to similar levels as the wild-type rBRSV in the bovine upper and lower respiratory tract [153]. However, both the FCS-2 and $\Delta$ p27 mutants induced significantly less pulmonary inflammation compared with the parental wild-type rBRSV [153]. Furthermore, calves infected with the $\mathrm{F}$ mutant viruses showed a marked reduction in the numbers of eosinophils in the lamina propria of the large bronchioles suggesting that the virokinin may play a role in eosinophil recruitment (Fig. 3). Nevertheless, the virokinin did not have any direct chemoattractant proprieties on inflammatory cells, in vitro [153]. The chemokines RANTES (CCL5) and MIP-1 $\alpha$ (CCL3) are potent attractants for human eosinophils and there is a correlation between levels of MIP- $1 \alpha$ and eosinophil cationic protein in the lower airways of infants with severe HRSV disease [58]. However, there were no significant differences in mRNA for either RANTES or MIP- $1 \alpha$ in the lungs of calves infected with the F mutant viruses, suggesting that these chemokines may not be involved in eosinophil recruitment in the calf [153].

The primary sequence of virokinin is conserved in all BRSV isolates studied to date [176], which suggests that it provides some selective advantage to the virus. Eosinophil products might be expected to have a detrimental effect on the virus, however these products might damage respiratory mucosa and induce ciliostasis, which could favour viral replication. In contrast to BRSV, the 27-mer peptide produced during the maturation of HRSV F does not contain a tachykinin motif [176] suggesting that virokinin may be an additional factor to chemokines involved in eosinophil recruitment in BRSV infection and/or may contribute to species specificity.
BRSV infection is associated with a reduction in mitogen-induced lymphocyte proliferation in both calves and lambs [66, $121,168]$. BRSV-infected cells are able to inhibit mitogen-induced lymphocyte proliferation, in vitro, and this effect was found to be mediated by direct contact of the lymphocytes with the F protein [116]. The precise mechanisms responsible for this inhibition are not known, however, contact with the F protein resulted in a defect or delay in the transit of lymphocytes from $\mathrm{G}_{0} / \mathrm{G}_{1}$ to S-phase. Although the implications of this suppressive effect for the pathogenesis of BRSV infection are not clear, it may contribute to a decrease in effector function of $\mathrm{CD}^{+} \mathrm{T}$ cells in the respiratory tract, which has been reported in HRSV-infected mice [28] and/or may influence the generation of BRSV-specific memory T cells.

\subsection{The role of the $G$ protein in the pathogenesis of BRSV}

As mentioned above, the $\mathrm{G}$ protein was thought to be the major attachment protein of RSV. However, recombinant BRSV and HRSV lacking the $G$ protein $(\Delta G)$, and or the SH protein, which is the other surface glycoprotein, can be rescued and such viruses replicate efficiently in cell culture $[65,135]$. Thus, the $\mathrm{F}$ protein alone is sufficient to mediate attachment and fusion in the absence of $\mathrm{G}$ and $\mathrm{SH}$. Whereas there is evidence that for HRSV, expression of the $G$ protein enhances binding of virus to tissue culture cells, cell-to-cell fusion and virion assembly and release [135], this was dependent upon the tissue culture cells [138] and a similar effect on BRSV replication in MDBK cells could not be demonstrated [65]. Analysis of the replication of rBRSV $\Delta \mathrm{G}$ in differentiated, bovine ciliated airway epithelial cell cultures has shown that although the virus can infect these cells, replication is slightly 
attenuated when compared with that of wild-type $\mathrm{rBRSV}^{5}$.

In contrast to the limited effects of the $\mathrm{G}$ protein on virus replication in vitro, expression of the $G$ protein is essential for significant replication of BRSV and HRSV in vivo $[118,138]$. Thus, following i.n. inoculation of calves within the first week of life with $\Delta G$ rBRSV, virus could not be re-isolated from the nasopharynx, although some virus replication was detected by RT-PCR, whereas the parental wild-type virus reached peak titres of approximately $10^{4} \mathrm{pfu} / \mathrm{mL}$ [118]. In these studies, the effects of $\Delta \mathrm{G}$ virus on lower respiratory tract infection were not investigated. However in mice infected with $\Delta \mathrm{G} H \mathrm{HRSV}$, although virus could not be recovered from the nasal turbinates, it could be isolated from the lungs of about $60 \%$ of the mice at titres that were 1000 -fold less than that from mice infected with wild-type HRSV [138].

In order to understand the role of the $G$ protein in the pathogenesis of RSV infection, further recombinant viruses expressing only the membrane-anchored $(\mathrm{Gm})$ or only the secreted form of the G (Gs) protein have been studied. Viruses expressing $\mathrm{Gm}$ were produced by introducing a point mutation in the second ATG of the viral G ORF encoding Met-48 to ATC encoding Ile-48 and viruses expressing Gs were made by deleting the first $141 \mathrm{nu}-$ cleotide segment encoding the cytoplasmic and part of the transmembrane domains of the G protein [138]. Recombinant viruses expressing only $\mathrm{Gm}$ or only Gs replicated as efficiently as the wild-type virus in cell culture $^{6}$ [138]. As shown for HRSVGs in

\footnotetext{
${ }^{5}$ Sadler R., Valarcher J.-F., Taylor G., unpublished observations.

${ }^{6}$ Sadler R., Buchholz U., Taylor G., The secreted form of the $G$ protein is a virulence determinant of bovine respiratory syncytial virus (BRSV), in: Abstracts of the 156th meeting of the Society for General Microbiology, 2005, pp. 80.
}

mice [138], studies in gnotobiotic calves have demonstrated that rBRSVGs is highly attenuated in the lungs and moderately attenuated in the nasopharynx, with peak titres in the nasopharynx approximately 100-fold less than that of the wild-type virus. Therefore BRSV only expressing Gs does not appear to be as attenuated as $\Delta \mathrm{G}$ virus suggesting that the function of $\mathrm{Gm}$ can be supplied, at least in part, by the secreted form of G. In studies investigating the replication of HRSVGm in the murine respiratory tract, HRSVGm replicated in nasal turbinates and lungs as efficiently as the wild-type virus [138], whereas in another study, the replication of this virus in the lungs was reduced 10-fold [89]. In cattle, although rBRSVGm replicated as efficiently as the wild-type virus in the upper airways, titres in the bronchoalveolar lavage (BAL) were 10-fold lower and there was little or no replication of the Gm virus in the lung parenchyma. Furthermore, in contrast to calves infected with wild-type rBRSV, animals infected with the Gm virus did not develop gross pneumonic lesions and microscopic lesions were minimal. These studies suggest that the secreted form of the $\mathrm{G}$ protein is important in establishing infection in the lower respiratory tract.

The mechanisms by which Gs mediates the establishment of LRT infection are not known, but it may be that this form of $\mathrm{G}$ binds to surfactant proteins in the lower respiratory tract, reducing their effects on the virion itself (Fig. 3). Support for this suggestion comes from the observations that susceptibility to severe HRSV infection in infants is linked to polymorphisms in SP-A and SP-D genes [76, 88] and SP-A deficient mice have more severe HRSV infection than their wild-type littermates [85]. Furthermore, there is evidence that the HRSV G protein can suppress TLR4-mediated cytokine production by monocytes and macrophages by inhibiting nuclear translocation of NF- $\mathrm{KB}$ [104] 
(Fig. 3). The mechanisms by which the $G$ protein mediates this effect are not known. However, the conserved cysteine-rich region of the $\mathrm{G}$ protein has homology with the fourth domain of the TNF receptor [80] and may inhibit components of the innate response by binding to $\mathrm{TNF} \alpha$ or an unknown TNF homologue. Studies with rHRSV lacking the cysteine-rich region of the $G$ protein suggest that although this region is not required for efficient viral replication in mice [139], it may play a role in suppressing the anti-viral T-cell response [56]. As mentioned previously, field isolates of BRSV have been identified that lack one or more of the cysteines in the central conserved region (see Sect. 2.1.3), but there is no information on the virulence of these isolates. Studies are in progress to determine the role of the central conserved cysteine-rich region in the pathogenesis of BRSV in calves.

\subsection{The role of the $\mathrm{SH}$ protein}

The role played by the SH protein during RSV replication is unclear. BRSV lacking the $\mathrm{SH}$ protein replicates as efficiently as the wild-type virus in cell culture [65]. However, there is some evidence from studies on HRSV that the SH protein may have a negative effect on virus fusion in cell culture [135]. When inoculated into mice, $\triangle \mathrm{SH} H \mathrm{HRS}$ resembled the parental wild-type virus in the efficiency of its replication in the lungs, whereas it replicated 10-fold less efficiently in the nasal turbinates [22]. These observations contrast with those of rBRSV $\triangle \mathrm{SH}$ in chimpanzees where virus replication was similar to that of the wild-type virus in the nose but was reduced 40-fold in tracheal lavage [167]. Preliminary studies in calves infected with rBRSV $\triangle \mathrm{SH}$ indicate that although the SH protein does not influence virus replication in the nasopharynx, it is important in establishing lower respiratory tract infection ${ }^{7}$. Thus like Gs, the SH protein may suppress some component(s) of the innate response important in mediating resistance of the lung to BRSV.

\subsection{The role of viral proteins in determining host-range specificity}

Although closely related, BRSV and HRSV display a highly restricted host range in vivo. Thus, there are no reports of BRSV infection in humans and there is little or no replication of BRSV in chimpanzees following experimental infection [21]. In contrast, although HRSV does not replicate very efficiently in the bovine nasopharynx, it replicates moderately well in the lungs and induces some pneumonic lesions following simultaneous i.n. and i.t. inoculation of young gnotobiotic calves [142]. Studies on the role of different viral proteins in determining hostrange restriction have demonstrated that the $\mathrm{F}$ and $\mathrm{G}$ proteins contribute to host range restriction but are not the major determinants [21]. Thus, whereas HRSV and BRSV replicated more efficiently in human and bovine cells respectively, rBRSV in which the $F$ and $G$ proteins had been replaced with those from HRSV exhibited intermediate growth characteristics in a human cell line and grew better than either parent in a bovine cell line. Furthermore, the chimaeric virus was more competent than BRSV for replication in chimpanzees, but remained highly restricted compared with HRSV.

Studies of HRSV and BRSV infection of differentiated respiratory epithelial cells, peripheral blood lymphocytes and macrophages also showed a pronounced host-range restriction [117]. Using recombinant HRSV and BRSV expressing chimaeric $\mathrm{F}$ proteins assembled from BRSV or HRSV F1 and F2 subunits, the species specificity correlated with the origin of the

\footnotetext{
${ }^{7}$ Taylor G., unpublished observations.
} 
F2 subunit [117]. Although the HRSV and BRSV G proteins have only $30 \%$ amino acid identity [83], the G protein did not appear to contribute to host-range restriction.

The NS proteins also appear to contribute to the host-range restriction of HRSV and BRSV. In a recombinant BRSV in which the NS genes were replaced with those from HRSV, the exchanged genes could fully substitute for BRSV NS1/NS2 in IFN $\alpha / \beta$-negative cells. However, in IFN-competent bovine cells, replication of rBRSV expressing HRSV NS1 and NS2 was attenuated [16]. Taken together, these studies indicate that hostrange restriction of HRSV and BRSV is dependent upon the actions of several proteins, including the $\mathrm{F}$ and NS proteins.

\section{PREVENTION, CONTROL AND VACCINATION}

Since the peak incidence of severe BRSV disease is between 2 and 6 months, an effective BRSV vaccine must be capable of stimulating an effective immune response within the first months of life. The presence of maternally-derived, RSVneutralising, serum antibodies poses a major obstacle to successful vaccination at this time. Furthermore, there is evidence from studies in man that vaccination can exacerbate RSV disease. Thus, a formalin-inactivated (FI)-HRSV vaccine not only failed to protect infants against HRSV infection but increased the severity of respiratory disease when they became infected $[64,67]$. Vaccine-augmented BRSV respiratory disease has been reproduced experimentally in calves [5, 47] and severe BRSV disease has been reported in calves vaccinated with a $\beta$ propiolactone-inactivated virus [119]. It is likely that a parenterally-administered, inactivated virus vaccine would not be effective in inducing a mucosal $\operatorname{IgA}$ antibody response, which would help to limit infection of the respiratory tract, and would not be effective in priming BRSV-specific $\mathrm{CD}^{+}$ $\mathrm{T}$ cells, which are important in eliminating virus [131]. Furthermore, there is evidence that the FI-HRSV induced antibodies were poorly neutralising [97]. Therefore, the absence of a strong mucosal and systemic protective immune response left the vaccinees susceptible to natural HRSV infection, whereupon the expression of viral antigens initiated an immunopathogenic response. It has been suggested that this immunopathogenic immune response may have been mediated by the deposition of immune complexes and complement activation in the lungs and/or the induction of a strong Th-2 biased immune response which resulted in the exaggerated recruitment of other inflammatory cells into the lungs $[35,36,51,103,163]$.

Whatever the mechanisms of vaccineaugmented disease may be, it has been proposed that since natural infection with RSV does not predispose to severe disease upon subsequent exposure to the virus, a live attenuated virus vaccine would induce the most appropriate protective immune response. Furthermore, the mucosal route of vaccination is more resistant to the immunosuppressive effects of maternal antibodies than the parenteral route of administration $[13,38]$. Whilst it is possible to generate live, attenuated viruses by passage in cell culture, it has been difficult to produce a genetically stable HRSV with an appropriate balance between attenuation and immunogenicity [34, 169]. Furthermore, we have increased the virulence of a BRSV isolate by sequential passage in gnotobiotic calves ${ }^{8}$. The ability to recover infectious recombinant BRSV from cDNA has greatly facilitated the production of live, attenuated, genetically stable vaccine candidates. Deletion of non-essential genes represents an attractive option for production of a live, attenuated virus vaccine, since they should be particularly refractory

\footnotetext{
${ }^{8}$ Taylor G., unpublished observations.
} 
to reversion and may be suitable as marker vaccines.

\subsection{NS deletion mutants as live vaccines}

As described above, the replication of NS deletion mutants of BRSV in the bovine respiratory tract is highly attenuated and does not result in the development of a pulmonary inflammatory response. Despite the poor replication of the NS deletion mutants, infection with either the $\triangle \mathrm{NS} 1$ or the $\triangle \mathrm{NS} 2$ mutant induced a BRSV-specific antibody response, primed BRSV-specific $\mathrm{CD}^{+}{ }^{+} \mathrm{T}$ cells and induced protection against a subsequent challenge with a virulent strain of BRSV [152]. Although there were no detectable differences in the ability of the $\triangle \mathrm{NS} 1$ or the $\triangle \mathrm{NS} 2$ mutants to replicate in the bovine respiratory tract, the $\Delta \mathrm{NS} 2 \mathrm{mu}-$ tant induced higher titres of neutralising serum antibodies, higher titres of BRSVspecific IgG2 antibodies, greater priming of BRSV-specific IFN $\gamma$-producing $\mathrm{CD}^{+}{ }^{+} \mathrm{T}$ cells and greater protection against a subsequent BRSV infection than the $\triangle \mathrm{NS} 1$ mutant. Since IFN $\alpha / \beta$ have profound immunomodulatory effects and can enhance the adaptive immune response, it has been suggested that the greater immunogenicity of the $\Delta \mathrm{NS} 2$ mutant is related to the greater ability of this virus to induce IFN $\alpha / \beta$ compared with the $\triangle \mathrm{NS} 1$ virus. Although the $\triangle \mathrm{NS} 2$ mutant was highly attenuated and immunogenic, it has not yet been evaluated in calves with maternal antibodies and it is possible that it will be too attenuated to induce an effective immune response in such animals.

\subsection{FCS-2 cleavage mutants or $\Delta$ p27 mutants as live vaccines}

Although disruption of furin-mediated cleavage at FCS-2 or deletion of pep27 did not affect virus replication in the bovine respiratory tract, viruses with these mutations induced little or no pulmonary inflammation, suggesting that they may be ideal live vaccine candidates. However, tachykinins are potent immunomodulators and it is possible that loss of expression of the virokinin may affect the induction of immunity. Studies in calves inoculated i.n. and i.t. demonstrated that neither disruption of furin-mediated cleavage at FCS-2 nor the loss of pep27 influenced the induction of BRSV-specific serum antibodies, as detected by ELISA, priming of BRSV-specific $\mathrm{T}$ cells, nor the induction of a protective immune response in young calves, 6 weeks after mucosal vaccination [153]. However, disruption of furinmediated cleavage at FCS-2, did appear to influence the induction of BRSV-specific neutralising antibodies, which were 10fold lower than those induced by either $\triangle \mathrm{p} 27$ or wild-type rBRSV. Thus, incomplete cleavage of the BRSV F protein appears to influence both the magnitude and the duration of neutralising antibodies.

\subsection{G protein mutants as live vaccines}

Recombinant BRSV lacking the G protein $(\Delta \mathrm{G})$ appears to be highly attenuated in calves inoculated via the i.n. route. Nevertheless, mucosal immunisation with the $\Delta \mathrm{G}$ virus induced serum neutralising antibodies, although the titres were 4 to 32-fold lower than those induced by the parental wild-type virus [118]. Following challenge with a virulent strain of BRSV, there was a significant reduction in virus titres in both the nasopharynx and the lungs of calves previously infected with the $\Delta \mathrm{G}$ virus. However, protection against challenge was not as great as that induced by the parental wild-type virus. These studies suggest that the $\Delta \mathrm{G}$ virus may be too attenuated to induce a fully protective immune response. Furthermore, the $\mathrm{G}$ protein is a major protective antigen and should ideally be present in a BRSV vaccine. 
In contrast to the $\Delta \mathrm{G}$ rBRSV, virus expressing only the membrane-anchored form of the $\mathrm{G}$ protein replicated as efficiently as the wild-type virus in the nasopharynx of calves but was attenuated in the lungs. Inoculation of calves by the i.n. and i.t. routes with rBRSVGm induced a serum antibody response and $\mathrm{T}$ cell response indistinguishable from that induced by wild-type $\mathrm{rBRSV}^{6}$. Furthermore, the Gm virus induced complete protection against subsequent challenge with a virulent strain of BRSV. These findings suggest that the rBRSVGm has promise as a live, attenuated virus vaccine candidate. However, it differs from wild-type BRSV by a single point mutation and the ability of this virus to revert to virulence on repeated passages in calves is not known.

\subsection{SH deletion mutants as live vaccines}

As described previously, rBRSV $\triangle \mathrm{SH}$ replicates as efficiently as wild-type virus in the bovine nasopharynx but is attenuated in the lungs making this virus a suitable vaccine candidate. Although the immunogenic potential of $\Delta \mathrm{SH}$ virus has not yet been evaluated in calves, inoculation of chimpanzees by the i.n. and i.t. routes with HRSV $\triangle \mathrm{SH}$ induced serum neutralising antibodies comparable to those induced by wild-type HRSV [167]. However, in this study the chimpanzees were not challenged with virulent HRSV.

\subsection{Other strategies for the development of live attenuated BRSV vaccine candidates}

Deletion of M2-2 in HRSV produced a virus that was attenuated and immunogenic in chimpanzees and a similar deletion mutant of rBRSV may also be a suitable vaccine candidate for calves. Apart from deleting non-essential genes, it is also possible to target a specific protein and replace charged amino acids with noncharged ones. This has been done with the HRSV L protein and a number of the mutations were attenuating [129]. Another strategy is to alter the order of the viral genes. Gene transcription in RSV, has a polar gradient such that genes proximal to the 3 ' promoter are expressed more efficiently than downstream genes (see Fig. 2). Rearrangement of the gene order might yield sub-optimal ratios of proteins and attenuate the virus. This method has been use for BRSV and we have demonstrated that altering the positions of the BRSV F and $G$ proteins to positions 3 and 4 in the genome instead of positions 7 and 8 (see Fig. 2) resulted in increased expression of the $\mathrm{F}$ and $\mathrm{G}$ proteins in vitro, attenuation of the virus in young calves and induced protection against subsequent challenge with virulent $\mathrm{BRSV}^{9}$. It may also be possible to introduce a gene encoding for a cytokine such as IL-2, IFN $\gamma$ or GMCSF into the BRSV genome. This has been done for HRSV and although such viruses were attenuated in mice, their ability to induce antibodies and/or prime $T$ cells was similar to that of wild-type HRSV [23-25]. Similarly, introduction of an extra gene such as green fluorescent protein into the viral genome has been shown to attenuate BRSV in young calves (unpublished observations). Recombinant BRSV expressing bovine IL-2 or IL-4 have been produced by replacing the $\mathrm{F}$ protein peptide pep 27 coding sequence with that of the bovine cytokine [72]. However, these recombinants have not been tested in cattle.

\section{CONCLUSIONS}

The ability to manipulate the genome of BRSV has increased our understanding of the role of different proteins in the

\footnotetext{
${ }^{9}$ Taylor G., Valarcher J.-F., Buchholz U., manuscript in preparation.
} 
pathogenesis of this virus in calves and has provided opportunities for the development of stable, live attenuated virus vaccines, administered by the mucosal route. This approach to vaccination may be more effective at inducing both mucosal and systemic immunity of longer duration compared to those that are on the market. All of the studies described in this review have used mutant viruses derived from BRSV strain ATue51908 [20,115], which appears to be attenuated when compared with more virulent BRSV strains. Thus, although the parental rBRSV strain ATue51908 replicates in both the nasopharynx and lungs and induces pneumonic lesions, it does not induce clinical signs of disease. Therefore, using this virus, it has not been possible to determine the role of various viral proteins in the development of clinical respiratory disease. For example, it was not possible to determine the effects of virokinin, produced as a result of cleavage of the $\mathrm{F}$ protein, on the development of bronchoconstriction in calves. Nevertheless, studies using mutants of this strain of BRSV have demonstrated the role of the NS proteins in inhibiting the IFN $\alpha / \beta$ response, a potential role for virokinin in eosinophil recruitment and a role for the $\mathrm{SH}$ protein and the secreted form of the $\mathrm{G}$ protein in establishing lower respiratory tract infections. In addition, a number of these mutants induced an immune response and protection against experimental BRSV infection comparable to that induced by wild-type BRSV and are therefore suitable vaccine candidates for the control of BRSV respiratory disease in the field.

\section{REFERENCES}

[1] Ahmadian G., Chambers P., Easton A.J., Detection and characterization of proteins encoded by the second ORF of the M2 gene of pneumoviruses, J. Gen. Virol. (1999) 80:2011-2016.

[2] Alansari H., Potgieter L.N., Molecular cloning and sequence analysis of the phos- phoprotein, nucleocapsid protein, matrix protein and $22 \mathrm{~K}(\mathrm{M} 2)$ protein of the ovine respiratory syncytial virus, J. Gen. Virol. (1994) 75:3597-3601.

[3] Ames T.R., The epidemiology of BRSV infection, Vet. Med. (1993) 88:881-885.

[4] Anderson K., King A.M., Lerch R.A., Wertz G.W., Polylactosaminoglycan modification of the respiratory syncytial virus small hydrophobic (SH) protein: a conserved feature among human and bovine respiratory syncytial viruses, Virology (1992) 191:417-430.

[5] Antonis A.F., Schrijver R.S., Daus F., Steverink P.J., Stockhofe N., Hensen E.J., Langedijk J.P., van der Most R.G., Vaccineinduced immunopathology during bovine respiratory syncytial virus infection: exploring the parameters of pathogenesis, J. Virol. (2003) 77:12067-12073.

[6] Arslanagic E., Matsumoto M., Suzuki K., Nerome K., Tsutsumi H., Hung T., Maturation of respiratory syncytial virus within HEp-2 cell cytoplasm, Acta Virol. (1996) 40:209-214.

[7] Atreya P.L., Peeples M.E., Collins P.L., The NS1 protein of human respiratory syncytial virus is a potent inhibitor of minigenome transcription and RNA replication, J. Virol. (1998) 72:1452-1461.

[8] Atreya P.L., Kulkarni S., Respiratory syncytial virus strain A2 is resistant to the antiviral effects of type I interferons and human MxA, Virology (1999) 261:227-241.

[9] Baker J.C., Ames T.R., Markham R.J., Seroepizootiologic study of bovine respiratory syncytial virus in a dairy herd, Am. J. Vet. Res. (1986) 47:240-245.

[10] Belanger F., Berthiaume L., Alain R., Lussier G., Trudel M., Electron microscopic evidence for bridges between bovine respiratory syncytial virus particles, J. Gen. Virol. (1988) 69:1421-1424.

[11] Belknap E., Baker J.C., Patterson J.S., Walker R.D., Haines D.M., Clark E.G., The role of passive immunity in bovine respiratory syncytial virus-infected calves, J. Infect. Dis. (1991) 163:470-476.

[12] Belknap E.B., Recognizing the clinical signs of BRSV infection, Vet. Med. (1993) 88:883-887.

[13] Belshe R.B., Van Voris L.P., Mufson M.A., Parenteral administration of live respiratory syncytial virus vaccine: results of a field trial, J. Infect. Dis. (1982) 145:311-319. 
[14] Bermingham A., Collins P.L., The M2-2 protein of human respiratory syncytial virus is a regulatory factor involved in the balance between RNA replication and transcription, Proc. Natl. Acad. Sci. USA (1999) 96:11259-11264.

[15] Bitko V., Velazquez A., Yang L., Yang Y.C., Barik S., Transcriptional induction of multiple cytokines by human respiratory syncytial virus requires activation of $N F-\kappa B$ and is inhibited by sodium salicylate and aspirin, Virology (1997) 232:369-378.

[16] Bossert B., Conzelmann K.-K., Respiratory syncytial virus (RSV) nonstructural (NS) proteins as host range determinants: a chimeric bovine RSV with NS genes from human RSV is attenuated in interferoncompetent bovine cells, J. Virol. (2002) 76:4287-4293

[17] Bossert B., Marozin S., Conzelmann K.K., Nonstructural proteins NS1 and NS2 of bovine respiratory syncytial virus block activation of interferon regulatory factor $3, \mathrm{~J}$. Virol. (2003) 77:8661-8668.

[18] Brown G., Aitken J., Rixon H.W.M., Sugrue R.J., Caveolin-1 is incorporated into mature respiratory syncytial virus particles during virus assembly on the surface of virus-infected cells, J. Gen. Virol. (2002) 83:611-621.

[19] Bryson D.E., Necroscopy findings associated with BRSV pneumonia, Vet. Med. (1993) 88:894-899.

[20] Buchholz U.J., Finke S., Conzelmann K.$\mathrm{K}$., Generation of bovine respiratory syncytial virus (BRSV) from cDNA:BRSV NS2 is not essential for virus replication in tissue culture, and the human RSV leader region acts as a functional BRSV genome promoter, J. Virol. (1999) 73:251-259.

[21] Buchholz U.J., Granzow H., Schuldt K., Whitehead S.S., Murphy B.R., Collins P.L., Chimeric bovine respiratory syncytial virus with glycoprotein gene substitutions from human respiratory syncytial virus (HRSV): Effects on host range and evaluation as a live-attenuated HRSV vaccine, J. Virol. (2000) 74:1187-1199.

[22] Bukreyev A., Whitehead S.S., Murphy B.R., Collins P.L., Recombinant respiratory syncytial virus from which the entire $\mathrm{SH}$ gene has been deleted grows efficiently in cell culture and exhibits site-specific attenuation in the respiratory tract of mice, J. Virol. (1997) 71:8973-8982.
[23] Bukreyev A., Whitehead S.S., Bukreyeva N., Murphy B.R., Collins P.L., Interferon $\gamma$ expressed by a recombinant respiratory syncytial virus attenuates virus replication in mice without compromising immunogenicity, Proc. Natl. Acad. Sci. USA (1999) 96:2367-2372.

[24] Bukreyev A., Whitehead S.S., Prussin C., Murphy B.R., Collins P.L., Effect of coexpression of interleukin-2 by recombinant respiratory syncytial virus on virus replication, immunogenicity, and production of other cytokines, J. Virol. (2000) 74:71517157.

[25] Bukreyev A., Belyakov I.M., Berzofsky J.A., Murphy P.M., Collins P.L., Granulocyte colony-stimulating factor expressed by recombinant respiratory syncytial virus attenuates viral replication and increases the level of pulmonary antigen-presenting cells, J. Virol. (2001) 75:12128-12140.

[26] Bunt A.A., Milne R.G., Sayaya T., Verbeek M., Vetten H.J., Walsh J.A., Paramyxoviridae, in: Fauquet C.M., Mayo M.A., Maniloff J., Desselberger U., Ball L.A. (Eds.), Virus taxonomy, Eigth report of the International Committee on Taxonomy of Viruses, Elsevier, Academic Press, London, 2005, pp. 655-671.

[27] Caldow G.L., Edwards S., Nixon P., Peters A.R., Associations between viral infection and respiratory disease in young beef bulls, Vet. Rec. (1988) 122:529-531.

[28] Chang J., Braciale T.J., Respiratory syncytial virus infection suppresses lung $\mathrm{CD}^{+}$ T-cell effector activity and peripheral CD8 ${ }^{+}$ T-cell memory in the respiratory tract, Nat. Med. (2002) 8:54-60.

[29] Citterio C.V., Luzzago C., Sala M., Sironi G., Gatti P., Gaffuri A., Lanfranchi P., Serological study of a population of alpine chamois (Rupicapra r rupicapra) affected by an outbreak of respiratory disease, Vet. Rec. (2003) 153:592-596.

[30] Collins P.L., Hill M.G., Johnson P.R., The two open reading frames of the $22 \mathrm{~K}$ mRNA of human respiratory syncytial virus: sequence comparison of antigenic subgroups $\mathrm{A}$ and $\mathrm{B}$ and expression in vitro, J. Gen. Virol. (1990) 71:3015-3020.

[31] Collins P.L., Mottet G., Oligomerization and post-translational processing of glycoprotein $\mathrm{G}$ of human respiratory syncytial virus: altered $\mathrm{O}$-glycosylation in the 
presence of brefeldin A, J. Gen. Virol (1992) 73:849-863.

[32] Collins P.L., Hill M.G., Camargo E., Grosfeld H., Chanock R.M., Murphy B.R., Production of infectious human respiratory syncytial virus from cloned cDNA confirms an essential role for the transcription elongation factor from the 5' proximal open reading frame of the $\mathrm{M} 2 \mathrm{mRNA}$ in gene expression and provides a capability for vaccine development, Proc. Natl. Acad. Sci. USA (1995) 92:11563-11567.

[33] Collins P.L., Chanock R.M., Murphy B.R., Respiratory syncytial virus, in: Kripe D.M., Howley P.M. (Eds.), Fields virology, 4th ed., Lippincott Williams and Wilkins, Philadelphia, 2001, pp. 1443-1485.

[34] Collins P.L., Murphy B.R., New generation live vaccines against human respiratory syncytial virus designed by reverse genetics, Proc. Am. Thorac. Soc. (2005) 2:166173.

[35] Connors M., Kulkarni A.B., Firestone C.Y., Holmes K.L., Morse H.C. III, Sotnkov A.V., Murphy B.R., Pulmonary histopathology induced by respiratory syncytial virus (RSV) challenge of formalin-inactivated RSV-immunised BALB/c mice is abrogated by depletion of CD4+ T-cells, J. Virol. (1992) 66:7444-7451.

[36] Connors M., Giese N.A., Kulkarni A.B., Firestone C.Y., Morse H.C., Murphy B.R., Enhanced pulmonary histopathology induced by respiratory syncytial virus (RSV) challenge of formalin-inactivated RSVimmunized BALB/c mice is abrogated by depletion of interleukin-4 (IL-4) and IL-10, J. Virol. (1994) 68:5321-5325.

[37] Conzelmann K.K., Reverse genetics of mononegavirales, Curr. Top. Microbiol. Immunol. (2004) 283:1-41.

[38] Crowe J.E. Jr., Bui P.T., Siber G.R., Elkins W.R., Chanock R.M., Murphy B.R., Cold-passaged, temperature-sensitive mutants of human respiratory syncytial virus (RSV) are highly attenuated, immunogenic, and protective in seronegative chimpanzees, even when RSV antibodies are infused shortly before immunization, Vaccine (1995) 13:847-855.

[39] De Jong M.C.M., Van der Poel W.H.M., Kramps J.A., Brand A., Van Oirschot J.T., Quantitative investigation of population persistence and recurrent outbreaks of bovine respiratory syncytial virus on dairy farms, Am. J. Vet. Res. (1996) 57:628-633.
[40] Dunbar M.R., Jessup D.A., Evermann J.F., Foreyt W.J., Seroprevalence of respiratory syncytial virus in free-ranging bighorn sheep, J. Am. Vet. Med. Assoc. (1985) 187:1173-1174.

[41] Elvander M., Severe respiratory disease in dairy cows caused by infection with bovine respiratory syncytial virus, Vet. Rec. (1996) 138:101-105

[42] Evans J.E., Cane P.A., Pringle C.R., Expression and characterisation of NS1 and NS2 proteins of respiratory syncytial virus, Virus Res. (1996) 43:155-161.

[43] Feldman S.A., Crim R.L., Audet S.A., Beeler J.A., Human respiratory syncytial virus surface glycoproteins $\mathrm{F}, \mathrm{G}$ and $\mathrm{SH}$ form an oligomeric complex, Arch. Virol. (2001) 146:2369-2383.

[44] Furze J., Wertz G., Lerch R., Taylor G., Antigenic heterogenicity of the attachment protein of bovine respiratory syncytial virus, J. Gen. Virol. (1994) 75:363-370.

[45] Furze J.M., Roberts S.R., Wertz G.W., Taylor G., Antigenically distinct G glycoproteins of BRSV strains share a high degree of genetic homogeneity, Virology (1997) 231:48-58.

[46] Gaddum R.M., Cook R.S., Furze J.M., Ellis S.A., Taylor G., Recognition of bovine respiratory syncytial virus proteins by bovine CD8+ T lymphocytes, Immunology (2003) 108:220-229.

[47] Gershwin L.J., Schelegle E.S., Gunther R.A., Anderson M.L., Woolums A.R., Larochelle D.R., Boyle G.A., Friebertshauser K.E., Singer R.S., A bovine model of vaccine enhanced respiratory syncytial virus pathophysiology, Vaccine (1998) 16:1225-1236.

[48] Ghildyal R., Hartley C., Varrasso A., Meanger J., Voelker D.R., Anders E.M., Mills J., Surfactant protein A binds to the fusion glycoprotein of respiratory syncytial virus and neutralizes virion infectivity, J. Infect. Dis. (1999) 180:2009-2013.

[49] Gonzalez-Reyes L., Ruiz-Arguello M.B., Garcia-Barreno B., Calder L., Lopez J.A., Albar J.P., Skehel J.J., Wiley D.C., Melero J.A., Cleavage of the human respiratory syncytial virus fusion protein at two distinct sites is required for activation of membrane fusion, Proc. Natl. Acad. Sci. USA (2001) 98:9859-9864.

[50] Goodbourn S., Didcock L., Randall R.E., Interferons: cell signalling, immune 
modulation, antiviral responses and virus countermeasures, J. Gen. Virol. (2000) 81:2341-2364.

[51] Graham B.S., Henderson G.S., Tang Y.W., Lu X., Neuzil K.M., Colley D.G., Priming immunization determines T helper cytokine mRNA expression patterns in lungs of mice challenged with respiratory syncytial virus, J. Immunol. (1993) 151:2032-2040.

[52] Haeberle H.A., Takizawa R., Casola A., Brasier A.R., Dieterich H.J., Van Rooijen N., Gatalica Z., Garofalo R.P., Respiratory syncytial virus-induced activation of nuclear factor-kappaB in the lung involves alveolar macrophages and toll-like receptor 4-dependent pathways, J. Infect. Dis. (2002) 186:1199-1206.

[53] Haeberle H.A., Casola A., Gatalica Z., Petronella S., Dieterich H.J., Ernst P.B., Brasier A.R., Garofalo R.P., I $\kappa$ B kinase is a critical regulator of chemokine expression and lung inflammation in respiratory syncytial virus infection, J. Virol. (2004) 78:2232-2241.

[54] Hagglund S., Svensson C., Emanuelson U., Valarcher J.F., Alenius S., Dynamics of virus infections involved in the bovine respiratory disease complex in Swedish dairy herds, Vet. J. (2006) 172:320-328.

[55] Hall C.B., Douglas R.G. Jr., Geiman J.M., Possible transmission by fomites of respiratory syncytial virus, J. Infect. Dis. (1980) 141:98-102.

[56] Harcourt J., Alvarez R., Jones L.P., Henderson C., Anderson L.J., Tripp R.A., Respiratory syncytial virus $\mathrm{G}$ protein and $\mathrm{G}$ protein CX3C motif adversely affect CX3CR1+ T cell responses, J. Immunol. (2006) 176:1600-1608.

[57] Hardy R.W., Wertz G.W., The product of the respiratory syncytial virus M2 gene ORF1 enhances readthrough of intergenic junctions during viral transcription, J. Virol. (1998) 72:520-526.

[58] Harrison A.M., Bonville C.A., Rosenberg H.F., Domachowske J.B., Respiratory syncytial virus-induced chemokine expression in the lower airways: eosinophil recruitment and degranulation, Am. J. Respir. Crit. Care Med. (1999) 159:1918-1924.

[59] Heminway B.R., Yu Y., Tanaka Y., Perrine K.G., Gustafson E., Bernstein J.M., Galinski M.S., Analysis of respiratory syncytial virus $\mathrm{F}, \mathrm{G}$, and $\mathrm{SH}$ proteins in cell fusion, Virology (1994) 200:801-805.
[60] Hendricks D.A., Baradaran K., McIntosh K., Patterson J.L., Appearance of a soluble form of the $\mathrm{G}$ protein of respiratory syncytial virus in fluids of infected cells, J. Gen. Virol. (1987) 68:1705-1714.

[61] Hendricks D.A., McIntosh K., Patterson J.L., Further characterization of the soluble form of the $\mathrm{G}$ glycoprotein of respiratory syncytial virus, J. Virol. (1988) 62:22282233.

[62] Hickling T.P., Bright H., Wing K., Gower D., Martin S.L., Sim R.B., Malhotra R., A recombinant trimeric surfactant protein D carbohydrate recognition domain inhibits respiratory syncytial virus infection in vitro and in vivo, Eur. J. Immunol. (1999) 29:3478-3484.

[63] Inaba Y., Tanaka Y., Sato K., Omori T., Matumoto M., Bovine respiratory syncytial virus - Studies on an outbreak in Japan, 1968-1969, Jpn. J. Microbiol. (1972) 16:373-383.

[64] Kapikian A.Z., Mitchell R.H., Chanock R.M., Shvedoff R.A., Stewart C.E., An epidemiologic study of altered clinical reactivity to respiratory syncytial (RS) virus infection in children previously vaccinated with an inactivated RS virus vaccine, Am. J. Epidemiol. (1969) 89:405-421.

[65] Karger A., Schmidt U., Buchholz U.J., Recombinant bovine respiratory syncytial virus with deletions of the $\mathrm{G}$ or $\mathrm{SH}$ genes: $\mathrm{G}$ and $\mathrm{F}$ proteins bind heparin, J. Gen. Virol. (2001) 82:631-640.

[66] Keles I., Woldehiwet Z., Murray R.D., In vitro studies on mechanisms of immunosuppression associated with bovine respiratory syncytial virus, J. Comp. Pathol. (1998) 118:337-345.

[67] Kim H.W., Canchola J.G., Brandt C.D., Pyles G., Chanock R.M., Jensen K., Parrott R.H., Respiratory syncytial virus disease in infants despite prior administration of antigenic inactivated vaccine, Am. J. Epidemiol. (1969) 89:422-434.

[68] Kimman T.G., Westenbrink F., Straver P.J., Van Zaane D., Schreuder B.E., Isotypespecific ELISAs for the detection of antibodies to bovine respiratory syncytial virus, Res. Vet. Sci. (1987) 43:180-187.

[69] Kimman T.G., Westenbrink F., Schreuder B.E., Straver P.J., Local and systemic antibody response to bovine respiratory syncytial virus infection and reinfection in calves with and without maternal antibodies, J. Clin. Microbiol. (1987) 25:1097-1106. 
[70] Kimman T.G., Zimmer G.M., Westenbrink F., Mars J., van Leeuwen E., Epidemiological study of bovine respiratory syncytial virus infections in calves: influence of maternal antibodies on the outcome of disease, Vet. Rec. (1988) 123:104-109.

[71] Kimman T.G., Straver P.J., Zimmer G.M., Pathogenesis of naturally acquired bovine respiratory syncytial virus infection in calves: morphologic and serologic findings, Am. J. Vet. Res. (1989) 50:684-693.

[72] Konig P., Giesow K., Schuldt K., Buchholz U.J., Keil G.M., A novel protein expression strategy using recombinant bovine respiratory syncytial virus (BRSV): modifications of the peptide sequence between the two furin cleavage sites of the BRSV fusion protein yield secreted proteins, but affect processing and function of the BRSV fusion protein, J. Gen. Virol. (2004) 85:18151824.

[73] Kuo L., Grosfeld H., Cristina J., Hill M.G., Collins P.L., Effects of mutations in the gene-start and gene-end sequence motifs on transcription of monocistronic and dicistronic minigenomes of respiratory syncytial virus, J. Virol. (1996) 70:6892-6901.

[74] Kuo L., Fearns R., Collins P.L., Analysis of the gene start and gene end signals of human respiratory syncytial virus: quasitemplated initiation at position 1 of the encoded mRNA, J. Virol. (1997) 71:49444953.

[75] Kurt-Jones E.A., Popova L., Kwinn L., Haynes L.M., Jones L.P., Tripp R.A., Walsh E.E., Freeman M.W., Golenbock D.T., Anderson L.J., Finberg R.W., Pattern recognition receptors TLR4 and CD14 mediate response to respiratory syncytial virus, Nat. Immunol. (2000) 1:398-401.

[76] Lahti M., Lofgren J., Marttila R., Renko M., Klaavuniemi T., Haataja R., Ramet M., Hallman M., Surfactant protein D gene polymorphism associated with severe respiratory syncytial virus infection, Pediatr. Res. (2002) 51:696-699.

[77] Lambert D.M., Role of oligosaccharides in the structure and function of respiratory syncytial virus glycoproteins, Virology (1988) 164:458-466.

[78] Langedijk J.P.M., Schaaper W.M.M., Meloen R.H., van Oirschot J.T., Proposed three-dimensional model for the attachment protein $\mathrm{G}$ or respiratory syncytial virus, $\mathrm{J}$. Gen. Virol. (1996) 77:1249-1257.
[79] Langedijk J.P., Meloen R.H., Taylor G., Furze J.M., van Oirschot J.T., Antigenic structure of the central conserved region of protein $\mathrm{G}$ of bovine respiratory syncytial virus, J. Virol. (1997) 71:4055-4061.

[80] Langedijk J.P., de Groot B.L., Berendsen H.J., van Oirschot J.T., Structural homology of the central conserved region of the attachment protein $G$ of respiratory syncytial virus with the fourth subdomain of $55-\mathrm{kDa}$ tumor necrosis factor receptor, Virology (1998) 243:293-302.

[81] Larsen L.E., Uttenthal A., Arctander P., Tjornehoj K., Viuff B., Rontved C., Ronshold L., Alexandersen S., Blixenkrone-Moller M., Serological and genetic characterisation of bovine respiratory syncytial virus (BRSV) indicates that Danish isolates belong to the intermediate subgroup: no evidence of a selective effect on the variability of $\mathrm{G}$ protein nucleotide sequence by prior cell culture adaption and passages in cell culture or calves, Vet. Microbiol. (1998) 62:265-279.

[82] Lehmkuhl H.D., Smith M.H., Cutlip R.C., Morphogenesis and ultrastructure of caprine respiratory syncytial virus, Arch. Virol. (1980) 65:269-276.

[83] Lerch R.A., Anderson K., Wertz G.W., Nucleotide sequence analysis and expression from recombinant vectors demonstrate that the attachment protein $\mathrm{G}$ of bovine respiratory syncytial virus is distinct from that of human respiratory syncytial virus, J. Virol. (1990) 64:5559-5569.

[84] Lerch R.A., Anderson K., Amann V.L., Wertz G.W., Nucleotide sequence analysis of the bovine respiratory syncytial virus fusion protein mRNA and expression from a recombinant vaccinia virus, Virology (1991) 181:118-131.

[85] LeVine A.M., Gwozdz J., Stark J., Bruno M., Whitsett J., Korfhagen T., Surfactant protein-A enhances respiratory syncytial virus clearance in vivo, J. Clin. Invest. (1999) 103:1015-1021.

[86] Levine S., Klaiber Franco R., Paradiso P.R., Demonstration that glycoprotein $G$ is the attachment protein of respiratory syncytial virus, J. Gen. Virol. (1987) 68:2521-2524.

[87] Lo M.S., Brazas R.M., Holtzman M.J., Respiratory syncytial virus nonstructural proteins NS1 and NS2 mediate inhibition of Stat 2 expression and alpha/beta interferon 
responsiveness, J. Virol. (2005) 79:93159319.

[88] Lofgren J., Ramet M., Renko M., Marttila R., Hallman M., Association between surfactant protein A gene locus and severe respiratory syncytial virus infection in infants, J. Infect. Dis. (2002) 185:283-289.

[89] Maher C.F., Hussell T., Blair E., Ring C.J., Openshaw P.J., Recombinant respiratory syncytial virus lacking secreted glycoprotein $\mathrm{G}$ is attenuated, non-pathogenic but induces protective immunity, Microbes Infect. (2004) 6:1049-1055.

[90] Malhotra R., Ward M., Bright H., Priest R., Foster M.R., Hurle M., Blair E., Bird M., Isolation and characterisation of potential respiratory syncytial virus receptor(s) on epithelial cells, Microbes Infect. (2003) 5:123-133.

[91] Mallipeddi S.K., Samal S.K., Sequence comparison between the phosphoprotein mRNAs of human and bovine respiratory syncytial viruses identifies a divergent domain in the predicted protein, J. Gen. Virol. (1992) 73:2441-2444.

[92] Mallipeddi S.K., Samal S.K., Sequence variability of the glycoprotein gene of bovine respiratory syncytial virus, J. Gen. Virol. 74 (1993) 2001-2004.

[93] Mallipeddi S.K., Lupiani B., Samal S.K., Mapping the domains on the phosphoprotein of bovine respiratory syncytial virus required for N-P interaction using a two-hybrid system, J. Gen. Virol. (1996) 77:1019-1023.

[94] Mars M.H., Bruschke C.J., van Oirschot J.T., Airborne transmission of BHV1, BRSV, and BVDV among cattle is possible under experimental conditions, Vet. Microbiol. (1999) 66:197-207.

[95] Miller A.L., Bowlin T.L., Lukacs N.W., Respiratory syncytial virus-induced chemokine production: linking viral replication to chemokine production in vitro and in vivo, J. Infect. Dis. (2004) 189:1419-1430.

[96] Monick M.M., Yarovinsky T.O., Powers L.S., Butler N.S., Carter A.B., Gudmundsson G., Hunninghake G.W., Respiratory syncytial virus up-regulates TLR4 and sensitizes airway epithelial cells to endotoxin, J. Biol. Chem. (2003) 278:53035-53044.

[97] Murphy B.R., Prince G.A., Walsh E.E., Kim H.W., Parrott R.H., Hemming V.G., Rodriguez W.J., Chanock R.M.,
Dissociation between serum neutralizing and glycoprotein antibody responses of infants and children who received inactivated respiratory syncytial virus vaccine, J. Clin. Microbiol. (1986) 24:197-202.

[98] Nettleton P.F., Gilray J.A., Caldow G., Gidlow J.R., Durkovic B., Vilcek S., Recent isolates of bovine respiratory syncytial virus from Britain are more closely related to isolates from USA than to earlier British and current mainland European isolates, J. Vet. Med. B Infect. Dis. Vet. Public Health (2003) 50:196-199.

[99] Noah T., Becker S., Chemokines in nasal secretions of normal adults experimentally infected with respiratory syncytial virus, Clin. Immunol. (2000) 97:43-49.

[100] Paccaud M.F., Jacquier C.L., A respiratory syncytial virus of bovine origin, Arch. Gesamte Virusforsch. (1970) 30:327-342.

[101] Pastey M.K., Samal S.K., Structure and sequence comparison of bovine respiratory syncytial virus fusion protein, Virus Res. (1993) 29:195-202.

[102] Pastey M.K., Samal S.K., Nucleotide sequence analysis of the non-structural NS1 (1C) and NS2 (1B) protein genes of bovine respiratory syncytial virus, J. Gen. Virol. (1995) 76:193-197.

[103] Polack F.P., Teng M.N., Collins P.L., Prince G.A., Exner M., Regele H., Lirman D.D., Rabold R., Hoffman S.J., Karp C.L., Kleeberger S.R., Wills-Karp M., Karron R.A., A role for immune complexes in enhanced respiratory syncytial virus disease, J. Exp. Med. (2002) 196:859-865.

[104] Polack F.P., Irusta P.M., Hoffman S.J., Schiatti M.P., Melendi G.A., Delgado M.F., Laham F.R., Thumar B., Hendry R.M., Melero J.A., Karron R.A., Collins P.L., Kleeberger S.R., The cysteine-rich region of respiratory syncytial virus attachment protein inhibits innate immunity elicited by the virus and endotoxin, Proc. Natl. Acad. Sci. USA (2005) 102:8996-9001.

[105] Prozzi D., Walravens K., Langedijk J.P., Daus F., Kramps J.A., Letesson J.J., Antigenic and molecular analyses of the variability of bovine respiratory syncytial virus G glycoprotein, J. Gen. Virol. (1997) 78:359-366.

[106] Ramaswamy M., Shi L., Varga S.M., Barik S., Behlke M.A., Look D.C., Respiratory syncytial virus nonstructural protein 2 specifically inhibits type I interferon signal 
transduction, Virology (2006) 344:328339.

[107] Rivera H., Madewell B.R., Ameghino E., Serologic survey of viral antibodies in the Peruvian alpaca (Lama pacos), Am. J. Vet. Res. (1987) 48:189-191.

[108] Roberts S.R., Lichtenstein D., Ball L.A., Wertz G.W., The membrane-associated and secreted forms of the respiratory syncytial virus attachment glycoprotein $\mathrm{G}$ are synthesized from alternative initiation codons, J. Virol. (1994) 68:4538-4546.

[109] Rontved C.M., Tjornehoj K., Viuff B., Larsen L.E., Godson D.L., Ronsholt L., Alexandersen S., Increased pulmonary secretion of tumor necrosis factor-alpha in calves experimentally infected with bovine respiratory syncytial virus, Vet. Immunol. Immunopathol. (2000) 76:199-214.

[110] Rudd B.D., Burstein E., Duckett C.S., Li X., Lukacs N.W., Differential role for TLR3 in respiratory syncytial virusinduced chemokine expression, J. Virol. (2005) 79:3350-3357.

[111] Samal S.K., Zamora M., Nucleotide sequence analysis of a matrix and small hydrophobic protein dicistronic mRNA of bovine respiratory syncytial virus demonstrates extensive sequence divergence of the small hydrophobic protein from that of human respiratory syncytial virus, J. Gen. Virol. (1991) 72:1715-1720.

[112] Samal S.K., Zamora M., McPhillips T.H., Mohanty S.B., Molecular cloning and sequence analysis of bovine respiratory syncytial virus mRNA encoding the major nucleocapsid protein, Virology (1991) 180:453-456.

[113] Sausker E.A., Dyer N.W., Seroprevalence of OHV-2, BVDV, BHV-1, and BRSV in ranch-raised bison (Bison bison), J. Vet. Diagn. Invest. (2002) 14:68-70.

[114] Schelcher F., Salat O., Bezille P., Espinasse J., Approche seroépidémiologique des troubles respiratoires épizootiques des veaux d'Aveyron : rôle du virus respiratoire syncytial, Rev. Med. Vet. (1990) 141:117-123.

[115] Schlender J., Bossert B., Buchholz U., Conzelmann K.-K., Bovine respiratory syncytial virus nonstructural proteins NS1 and NS2 cooperatively antagonize alpha/beta interferon-induced antiviral response, $\mathrm{J}$. Virol. (2000) 74:8234-8242.

[116] Schlender J., Walliser G., Fricke J., Conzelmann K.-K., Respiratory syncytial virus fusion protein mediates inhibition of mitogen-induced T-cell proliferation by contact, J. Virol. (2002) 76:1163-1170.

[117] Schlender J., Zimmer G., Herrler G., Conzelmann K.-K., Respiratory syncytial virus (RSV) fusion protein subunit F2, not attachment protein $\mathrm{G}$, determines the specificity of RSV infection, J. Virol. (2003) 77:4609-4616.

[118] Schmidt U., Breyer J., Polster U., Gershwin L.J., Buchholz U., Mucosal immunization with live recombinant bovine respiratory syncytial virus (BRSV) and recombinant BRSV lacking the envelope glycoprotein G protects against challenge with wild-type BRSV, J. Virol. (2002) 76:12355-12359.

[119] Schreiber P., Matheise J.P., Dessy F., Heimann M., Letesson J.J., Coppe P., Collard A., High mortality rate associated with bovine respiratory syncytial virus (BRSV) infection in Belgian white blue calves previously vaccinated with an inactivated vaccine, J. Vet. Med. B Infect. Dis. Vet. Public Health (2000) 47:535-550.

[120] Schrijver R.S., Daus F., Kramps J.A., Langedijk J.P., Buijs R., Middel W.G., Taylor G., Furze J., Huyben M.W., van Oirschot J.T., Subgrouping of bovine respiratory syncytial virus strains detected in lung tissue, Vet. Microbiol. (1996) 53:253260.

[121] Sharma R., Woldehiwet Z., Depression of lymphocyte responses to phytohaemagglutinin in lambs experimentally infected with bovine respiratory syncytial virus, Res. Vet. Sci. (1991) 50:152-156.

[122] Smith M.H., Frey M.L., Dierks R.E., Isolation and characterisation of a bovine syncytial virus, Vet. Rec. (1974) 94:599.

[123] Smith M.H., Lehmkhul H.D., Phillips S.M.I., Isolation and characterization of respiratory syncytial virus from goats, Am. Assoc. Vet. Lab. Diagn. (1979) 22:259 269.

[124] Spann K.M., Tran K.C., Chi B., Rabin R.L., Collins P.L., Suppression of the induction of alpha, beta, and lambda interferons by the NS1 and NS2 proteins of human respiratory syncytial virus in human epithelial cells and macrophages, J. Virol. (2004) 78:4363-4369.

[125] Spann K.M., Tran K.C., Collins P.L., Effects of nonstructural proteins NS1 and NS2 of human respiratory syncytial virus on interferon regulatory factor $3, \mathrm{NF}-\kappa \mathrm{B}$, 
and proinflammatory cytokines, J. Virol. (2005) 79:5353-5362.

[126] Spilki F.R., Almeida R.S., Domingues H.G., D'Arce R.C., Ferreira H.L., Campalans J., Costa S.C., Arns C.W., Phylogenetic relationships of Brazilian bovine respiratory syncytial virus isolates and molecular homology modeling of attachment glycoprotein, Virus Res. (2006) 116:30-37.

[127] Stott E.J., Thomas L.H., Collins A.P., Crouch S., Jebbett J., Smith G.S., Luther P.D., Caswell R., A survey of virus infections of the respiratory tract of cattle and their association with disease, J. Hyg. (Lond.) (1980) 85:257-270.

[128] Stott E.J., Taylor G., Respiratory syncytial virus. Brief review, Arch. Virol. (1985) 84:1-52.

[129] Tang R.S., Nguyen N., Zhou H., Jin H., Clustered charge-to-alanine mutagenesis of human respiratory syncytial virus $\mathrm{L}$ polymerase generates temperature-sensitive viruses, Virology (2002) 302:207-216.

[130] Taylor G., Stott E.J., Furze J., Ford J., Sopp P., Protective epitopes on the fusion protein of respiratory syncytial virus recognized by murine and bovine monoclonal antibodies, J. Gen. Virol. (1992) 73:2217-2223.

[131] Taylor G., Thomas L.H., Wyld S.G., Furze J., Sopp P., Howard C.J., Role of Tlymphocyte subsets in recovery from respiratory syncytial virus infection in calves, $\mathrm{J}$. Virol. (1995) 69:6658-6664.

[132] Taylor G., Thomas L.H., Furze J.M., Cook R.S., Wyld S.G., Lerch R., Hardy R., Wertz G.W., Recombinant vaccinia viruses expressing the $\mathrm{F}, \mathrm{G}$ or $\mathrm{N}$, but not the $\mathrm{M} 2$, protein of bovine respiratory syncytial virus (BRSV) induce resistance to BRSV challenge in the calf and protect against the development of pneumonic lesions, J. Gen. Virol. (1997) 78:3195-3206.

[133] Taylor G., Rijsewijk F.A.M., Thomas L.H., Wyld S.G., Gaddum R.M., Cook R.S., Morrison W.I., Hensen E., van Oirschot J.T., Keil G., Resistance to bovine respiratory syncytial virus (BRSV) induced in calves by a recombinant bovine herpesvirus-1 expressing the attachment glycoprotein of BRSV, J. Gen. Virol. (1998) 79:1759-1767.

[134] Taylor G., Bruce C., Barbet A.F., Wyld S.G., Thomas L.H., DNA vaccination against respiratory syncytial virus in young calves, Vaccine (2005) 23:1242-1250.
[135] Techaarpornkul S., Baretto N., Peeples M.E., Functional analysis of recombinant respiratory syncytial virus deletion mutants lacking the small hydrophobic and/or attachment glycoprotein gene, J. Virol. (2001) 75:6825-6834.

[136] Teng M.N., Collins P.L., Identification of the respiratory syncytial virus proteins required for formation and passage of helperdependent infectious particles, J. Virol. (1998) 72:5707-5716.

[137] Teng M.N., Collins P.L., Altered growth characteristics of recombinant respiratory syncytial viruses which do not produce NS2 protein, J. Virol. (1999) 73:466-473.

[138] Teng M.N., Whitehead S.S., Collins P.L., Contribution of the respiratory syncytial virus $\mathrm{G}$ glycoprotein and its secreted and membrane-bound forms to virus replication in vitro and in vivo, Virology (2001) 289:283-296.

[139] Teng M.N., Collins P.L., The central conserved cystine noose of the attachment $G$ protein of human respiratory syncytial virus is not required for efficient viral infection in vitro or in vivo, J. Virol. (2002) 76:61646171.

[140] Thomas L.H., Stott E.J., Jones P.W., Jebbett N.J., Collins A.P., The possible role of respiratory syncytial virus and Pasteurella spp. in calf respiratory disease, Vet. Rec. (1980) 107:304-307.

[141] Thomas L.H., Stott E.J., Collins A.P., Jebbett J., Experimental pneumonia in gnotobiotic calves produced by respiratory syncytial virus, Br. J. Exp. Pathol. (1984) 65:19-28.

[142] Thomas L.H., Stott E.J., Collins A.P., Crouch S., Jebbett J., Infection of gnotobiotic calves with a bovine and human isolate of respiratory syncytial virus. Modification of the response by dexamethasone, Arch. Virol. (1984) 79:67-77.

[143] Thomas L.H., Cook R.S., Howard C.J., Gaddum R.M., Taylor G., Influence of selective T-lymphocyte depletion on the lung pathology of gnotobiotic calves and the distribution of different T-lymphocyte subsets following challenge with bovine respiratory syncytial virus, Res. Vet. Sci. (1996) 61:38-44.

[144] Thomas L.H., Cook R.S., Wyld S.G., Furze J.M., Taylor G., Passive protection of gnotobiotic calves using monoclonal antibodies directed at different epitopes on the 
fusion protein of bovine respiratory syncytial virus, J. Infect. Dis. (1998) 177:874880.

[145] Tjornehoj K., Uttenthal A., Viuff B., Larsen L.E., Rontved C., Ronsholt L., An experimental infection model for reproduction of calf pneumonia with bovine respiratory syncytial virus (BRSV) based on one combined exposure of calves, Res. Vet. Sci. (2003) 74:55-65.

[146] Tripp R.A., Jones L.P., Haynes L.M., Zheng H.Q., Murphy P.M., Anderson L.J., CX3C chemokine mimicry by respiratory syncytial virus G glycoprotein, Nat. Immunol. (2001) 2:732-738.

[147] Trudel M., Nadon F., Simard C., Belanger F., Alain R., Seguin C., Lussier G., Comparison of caprine, human and bovine strains of respiratory syncytial virus, Arch. Virol. (1989) 107:141-149.

[148] Ulloa L., Serra R., Asenjo A., Villanueva N., Interactions between cellular actin and human respiratory syncytial virus (HRSV), Virus Res. (1998) 53:13-25.

[149] Uttenthal A., Jensen N.P., Blom J.Y., Viral aetiology of enzootic pneumonia in Danish dairy herds: diagnostic tools and epidemiology, Vet. Rec. (1996) 139:114-117.

[150] Valarcher J.-F., Schelcher F., Bourhy H., Evolution of bovine respiratory syncytial virus, J. Virol. (2000) 74:10714-10728.

[151] Valarcher J.F., Bourhy H., Lavenu A., Bourges-Abella N., Roth M., Andreoletti O., Ave P., Schelcher F., Persistent infection of B lymphocytes by bovine respiratory syncytial virus, Virology (2001) 291:55-67.

[152] Valarcher J.-F., Furze J., Wyld S., Cook R., Conzelmann K.-K., Taylor G., Role of type I interferons in the attenuation and immunogenicity of recombinant bovine respiratory syncytial viruses (BRSV) lacking NS proteins, J. Virol. (2003) 77:8426-8439.

[153] Valarcher J.F., Furze J.M., Wyld S.G., Cook R., Zinkernagel R.M., Herrler G., Taylor G., Bovine respiratory syncytial virus lacking the virokinin or with a mutation in furin cleavage site $\mathrm{RA}(\mathrm{R} / \mathrm{K}) \mathrm{R}^{109}$ induces less pulmonary inflammation without impeding the induction of protective immunity in calves, J. Gen. Virol. (2006) 87:1659-1667.

[154] Valentova V., Antonis A.F., Kovarcik K., Restriction enzyme analysis of RT-PCR amplicons as a rapid method for detection of genetic diversity among bovine respiratory syncytial virus isolates, Vet. Microbiol. (2005) 108:1-12.

[155] Van der Poel W.H.M., Kramps J.A., Middel W.G.J., Van Oirschot J.T., Brand A., Diagnosis of bovine respiratory syncytial virus infections: a longitudinal epidemiological study in dairy herds, Arch. Virol. (1993) 133:309-321.

[156] Van der Poel W.H.M., Brand A., Kramps A., van Oirschot J.T., Respiratory syncytial virus infections in human beings and in cattle, J. Infect. Dis. (1994) 29:215-228.

[157] Van der Poel W.H.M., Langedijk J.P.M., Kramps J.A., Middel W.G.J., Brand A., Van Oirschot J.T., Bovine respiratory syncytial virus antibodies in non-bovine species, Arch. Virol. (1995) 140:1549-1555.

[158] Van der Poel W.H.M., Langedijk J.P.M., Kramps J.A., Middel W.G.J., Brand A., Van Oirschot J.T., Serological indication for persistence of bovine respiratory syncytial virus in cattle and attempts to detect the virus, Arch. Virol. (1997) 142:1682-1696.

[159] Verhoeff J., Van der Ban M., van Nieuwstadt A.P., Bovine respiratory syncytial virus infections in young dairy cattle: clinical and haematological findings, Vet. Rec. (1984) 114:9-12.

[160] Verhoeff J., van Nieuwstadt A.P., BRS virus, PI3 virus and BHV1 infections of young stock on self-contained dairy farms: epidemiological and clinical findings, Vet. Rec. (1984) 114:288-293.

[161] Viuff B., Uttenthal A., Tegtmeier C., Alexandersen S., Sites of replication of bovine respiratory syncytial virus in naturally infected calves as determined by in situ hybridisation, Vet. Pathol. (1996) 33:383-390.

[162] Viuff B., Tjornehoj K., Larsen L.E., Rontved C.M., Uttenthal A., Ronsholt L., Alexandersen S., Replication and clearance of respiratory syncytial virus. Apoptosis is an important pathway of virus clearance after experimental infection with bovine respiratory syncytial virus, Am. J. Pathol. (2002) 161:2195-2207.

[163] Waris M.E., Tsou C., Erdman D.D., Zaki S.R., Anderson L.J., Respiratory syncytial virus infection in BALB/c mice previously immunized with formalin-inactivated virus induces enhanced pulmonary inflammatory response with a predominant Th2-like 
cytokine pattern, J. Virol. (1996) 70:28522860.

[164] Weber E., Humbert B., Streckert H.-J., Werchau H., Nonstructural protein 2 (NS2) of respiratory syncytial virus (RSV) detected by an antipeptide serum, Respiration (1995) 62:27-33.

[165] Wertz G.W., Collins P.L., Huang Y., Gruber C., Levine S., Ball L.A., Nucleotide sequence of the $\mathrm{G}$ protein gene of human respiratory syncytial virus reveals an unusual type of membrane protein, Proc. Natl. Acad. Sci. USA (1985) 82:4075-4079.

[166] Wertz G.W., Krieger M., Ball L.A., Structure and cell surface maturation of the attachment glycoprotein of human respiratory syncytial virus in a cell line deficient in O glycosylation, J. Virol. (1989) 63:47674776.

[167] Whitehead S.S., Bukreyev A., Teng M.N., Firestone C.-Y., St. Claire M., Elkins W.R., Collins P.L., Murphy B.R., Recombinant respiratory syncytial virus bearing a deletion of either the NS2 or SH gene is attenuated in chimpanzees, J. Virol. (1999) 73:3438-3442.

[168] Woldehiwet Z., Sharma R., Evidence of immunosuppression by bovine respiratory syncytial virus, Scand. J. Immunol. (1992) Suppl. 11:75-80.

[169] Wright P.F., Belshe R.B., Kim H.W., Van Voris L.P., Chanock R.M., Administration of a highly attenuated, live respiratory syncytial virus vaccine to adults and children, Infect. Immun. (1982) 37:397-400.

[170] Yaegashi G., Seimiya Y.M., Seki Y., Tsunemitsu H., Genetic and antigenic analyses of bovine respiratory syncytial virus detected in Japan, J. Vet. Med. Sci. (2005) 67:145-150.

[171] Yunus A.S., Collins P.L., Samal S.K., Sequence analysis of a functional polymerase (L) gene of bovine respiratory syncytial virus: determination of minimal trans-acting requirements for RNA replication, J. Gen. Virol. (1998) 79:2231-2238.

[172] Zamora M., Samal S.K., Sequence analysis of M2 mRNA of bovine respiratory syncytial virus obtained from an F-M2 dicistronic mRNA suggests structural homology with that of human respiratory syncytial virus, $\mathrm{J}$. Gen. Virol. (1992) 73:737-741.

[173] Zhang L., Peeples M.E., Boucher R.C., Collins P.L., Pickles R.J., Respiratory syncytial virus infection of human airway epithelial cells is polarized, specific to ciliated cells, and without obvious cytopathology, J. Virol. (2002) 76:5654-5666.

[174] Zimmer G., Budz L., Herrler G., Proteolytic activation of respiratory syncytial virus fusion protein, J. Biol. Chem. (2001) 276:31642-31650.

[175] Zimmer G., Conzelmann K.-K., Herrler G., Cleavage at the furin consensus sequence $\mathrm{RAK} / \mathrm{KR}^{109}$ and presence of the intervening peptide of the respiratory syncytial virus fusion protein are dispensable for virus replication in cell culture, J. Virol. (2002) 76:9218-9224.

[176] Zimmer G., Rohn M., McGregor G.P., Schemann M., Conzelmann K.K., Herrler G., Virokinin, a bioactive peptide of the tachykinin family, is released from the fusion protein of bovine respiratory syncytial virus, J. Biol. Chem. (2003) 278:4685446861. 